\title{
A Szakmai Fejlesztő Iskola mint a pedagógusképzés megújításának egyik lehetséges modellje
}

\section{Zagyváné Szücs Ida}

az Eszterházy Károly Egyetem Neveléstudományi Doktori Iskolájának hallgatója szida5@gmail.com

A pedagógusképzés megújításának számos alternatívája közül az egyik megközelítés a pedagógusok szakmai fejlődését helyezi a középpontba. Tanulmányunkban egy a közelmúltban lezajlott kutatás részeredményeit ismertetjük azzal a céllal, hogy empirikus vizsgálatok alapján bemutassuk egy pedagógusképző intézet és annak gyakorlóiskolája által nyújtott lehetőségeket a jövő pedagógusainak számára a szakmai fejlesztés területén, valamint a jelen helyzetet mérlegelve javaslatokat fogalmazzunk meg egy új modell, a Szakmai Fejlesztő Iskola magyarországi bevezetésének irányában.

Kulcsszavak: pedagógusképzés, szakmai önfejlesztés, szakmai fejlesztő iskola, gyakorlóiskola

DOI: 10.37205/TEL-hun.2019.1-2.06

A pedagógusképzés megújítását sok szempontból közelíthetjük meg. Az egyik ilyen az iskolák önfejlesztő tevékenysége, azon belül pedig a pedagógusok képzése és továbbképzése. A jelenleg fennálló képzési rendszer továbbfejlesztéséhez fontos a gyakorlóiskolák Szakmai Fejlesztő Iskolákká történő átalakítása. Magyarországon a gyakorlati képzés meghatározó színhelye a gyakorlóiskola. Ez az a közeg, ahol a képzés összes résztvevője - ha különböző formákban is -, de kapcsolatba kerül egymással. Jelen tanulmányunkban egy, a közelmúltban lezajlott kutatás (Egy gyakorlóiskola eredményességét befolyásoló tényezők) részeredményeit ismertetjük lehetséges alternatívát nyújtva a magyar pedagógusképzés megújítására.

\section{A kutatás célja és módszerei}

A kutatás célja a szakmai önfejlesztés folyamatának a vizsgálata volt egy adott gyakorlóiskola példáján keresztül. A kutatás során arra kerestük a választ, hogy a Szakmai Fejlesztő Iskola elvárásait szem előtt tartva milyen az Eszterházy Károly Egyetem gyakorlóiskolájának jelenlegi szintje, és hogy a kitűzött cél eléréséhez 
milyen lépések szükségesek. A vizsgált területek közül jelen tanulmányban a pedagógusok, oktatók, hallgatók, diákok és szüleik az iskola önfejlesztő tevékenységére vonatkozó nézeteire koncentráltunk.

A kutatás során két fó kutatási módszert alkalmaztunk: dokumentumelemzést (pedagógiai program, versenyeredmények, pályázatok adatai), valamint írásbeli kikérdezést pedagógusokkal (100-130fó), tanulókkal (250fö), szülőkkel (250fó), tanárjelöltekkel (22 fö), egyetemi oktatókkal (16 fö) és beiskolázás előtt álló szülőkkel (jelentkező óvodások szülei: 102 fő és nyolcadik osztályosok szülei: 293 fó).

Az egyes populációk esetében eltérő nagyságú minta kiválasztására törekedtünk. Reprezentatív minta választását a kutatás nem indokolta és nem is tette lehetővé. A vizsgálat szempontjából három nagy populáció (szülők, pedagógusok és tanulók) véleményét tartottuk fontosnak. A pedagógusok esetében teljes körü mintavételre törekedtünk. Számukra három kérdoévet készítettünk. A kikérdezés során 60-70\%-os válaszadási arányt sikerült elérnünk. A szülők és a tanulók által teljességgel kitöltött kérdőívek száma több, mint kétszerese volt a pedagógusok által kitöltött kérdőíveknek, százalékos arányuk meghaladta a 15\%-ot. A beiskolázás előtt álló gyermekek szüleinél a minden kérdésre válaszolók alacsony aránya okozott gondot, mégis kirajzolódtak bizonyos tendenciák, ami a gyakorlatban is használható következtetések megfogalmazását tette lehetővé. Szintén kérdőíves vizsgálatot végeztünk az iskolával kapcsolatban lévő oktatók és a tanárjelöltek körében. Esetükben a két populáció meglehetősen kicsi, a válaszolási hajlandóság pedig alacsony volt. A vizsgálat során arra törekedtünk, hogy a különböző minták számára azonos kérdéseket is tegyünk fel, így biztosítva a különböző mintákból származó adatok kölcsönös kontrollját és következtetéseink megbízhatóságát. Vizsgálati eredményeink alapján a pedagógusképzésben résztvevő valamennyi szereplő számára fogalmaztunk meg javaslatokat bízva azok megfontolásában.

\section{Elméleti alapozás}

A pedagógusképzés mai magyar gyakorlatában a képző egyetem és a gyakorlóiskola az a színhely, ahol a tanárjelöltek elsajátíthatják a pedagógus szakma kezdeti fogásait. A két intézmény alá-fölérendeltségi viszonyban vannak egymással. Érdemes azonban kitekinteni a nagyvilágba, ahol az együttműködéseknek számtalan módja lehetséges. Az Egyesült Királyságban megvalósult együttmüködési formákat írták le Furlong és munkatársai (2006, idézi Kopp - Kálmán, 2015): 
- Párhuzamos-, vagy kiegészítő partnerség, amelyben a résztvevő intézmények eltérő feladatokkal, önálló felelősségi körrel rendelkeznek, a munkájuk során ezek a körök nem integrálódnak szerves egységgé.

- A képzőhely által vezetett partnerség, amelyben alá-fölérendeltségi viszony a meghatározó. A képzőhely határozza meg és irányítja a gyakorlatot.

- Együttmúködő partnerség, amelyben a képzés folyamatában a felsőoktatási intézmények és a gyakorlóhelyek együtt dolgoznak ki képzési programot, a hallgatók különböző tudásbázisból meríthetnek. A képzőhely és a gyakorlóhely által nyújtott tudásbázis egymással való összehasonlítása, ütköztetése révén a hallgatók maguk építik fel saját szakmai tudásukat. Az egyes résztvevők között rendszeresek a kapcsolatok, mivel közösek a feladatok és a tevékenységek.

Ugyanebben a munkájukban Furlong és munkatársai a National Partnership Project című kutatás eredményességére vonatkozóan fogalmaztak meg következtetéseket. Vizsgálatuk alapján kimutatták, hogy bár a deklarációk szintjén az együttműködő partnerség megvalósítása volt a Project célja, a valódi partneri viszony kiépítése olyan hosszan tartó és a résztvevők állandó egyeztetését igénylő folyamat, amelyet a NPP-project sem tudott megvalósítani. Sokszor a képzőhely által vezetett partnerségi folyamatok erősödtek fel. A kutatás eredményeként fogalmazták meg azokat a feltételeket, amelyek a sikeres együttműködéshez nélkülözhetetlenek:

- a résztvevők közti állandó, szervezett, kölcsönös és tiszteleten alapuló kommunikáció;

- a gyakorlat beépülése a gyakorlóhely tevékenységének teljes spektrumába (az intézmény működésének és a működés értékelésének szerves része a gyakorlat);

- a felelősségek, kötelességek és jogok résztvevők közti világos, részletes meghatározása.

Európán kívül egy sokkal integráltabb szervezeti modell valósult meg, melynek alapelve az egyenrangú együttmúködés. Az USA-ban a '80-as '90-es években dolgozták ki a Szakmai Fejlesztő Iskolák (Professional Development School, PDS) koncepcióját, amelynek célja a pedagógusképzés színvonalának javítása és a lemorzsolódás csökkentése volt (The Holmes Group, 1986, 1990). A Szakmai Fejlesz- 
tő Iskola mint szervezeti modell fennállása során a következő változásokat élte meg:

- A '80-as években ez a modell, mint új kezdeményezés volt jelen a pedagógusképzésben és csak néhány egyetem tartotta alkalmasnak arra a koncepciót, hogy képzési rendszerét erre a modellre építse. Mára már a pedagógusképzés központi, meghatározó elvévévé vált az USA-ban.

- A számbeli növekedéssel és szervezeti fejlesztéssel egy időben pontosításra kerültek a Szakmai Fejlesztő Iskola alapelvei.

- Részletesebb meghatározásra kerültek a Szakmai Fejlesztő Iskola értékelésének alapelvei. A hangsúly elsősorban arra került, hogy a szervezeti modellben végbemenő folyamatok mennyiben járulnak hozzá a diákok, a hallgatók és az oktatók tanulási eredményeinek a növekedéséhez.

- Fokozatosan előtérbe került a méltányosság, azaz a társadalmi különbségek méltányos kezelése a szervezeti modell által biztosított keretek között.

A modell céljait a következők szerint határozhatjuk meg (Darling-Hammond, 1994):

- felkészíteni a hallgatókat, majd a gyakornokokat a pedagógus hivatásra;

- javítani a pedagógusok munkakörülményeit;

- növelni a nevelés-oktatás színvonalát;

- megteremteni a pedagógusok és az iskolavezetők számára a magas színvonalú szakmai munka feltételeit.

Jelenleg az Amerikai Egyesült Államokban müködő Tanárképzés Nemzeti Akkreditációs Tanács (NCATE) a Szakmai Fejlesztő Iskolák (PDS) számára a következő irányelveket tartja mérvadónak (PDS Standards, NCATE, 2016):

- A Szakmai Fejlesztő Iskola (PDS) egy olyan tanulói közösség, amely egyszerre támogatja a tanulók fejlődését és a pedagógusok szakmai fejlődését.

- Elszámoltathatóság és minőségbiztosítás, azaz a szakmai fejlesztő iskola feladata olyan sztenderdek kidolgozása, amelyek biztosítják a tanulás és a tanítás magas színvonalát.

- Az iskola és a tanárképző intézmény együttműködése.

- Egyenlőség és különbözőség, azaz a szakmai fejlesztő iskola olyan szakembereket képez, akik képesek az eltérő igényekkel bíró tanulók felkészítésére.

- Olyan infrastruktúra létrehozása és fenntartása, amely biztosítja a magas színvonalú munka végzését. 
A fentebb említett sztenderdek nem képezik a Nemzeti Akkreditációs Tanács hivatalos akkreditációs elveinek a részét. A sztenderdeknek más szerepük van. Egyrészt a Szakmai Fejlesztő Iskolák önértékelésüknél használják azokat. Fontos ezen kívül, hogy akár földrajzi elvek, akár hálózatok (egyetemek és gyakorlóhelyek) mentén szerveződnek a Szakmai Fejlesztő Iskolák a belépő intézmények számára az elvek iránymutatásként szolgálnak. Továbbá, az intézmények egyedi és a teljes intézményi rendszer éves szintủ értékeléséhez biztosítanak alapot. Végül, de nem utolsó sorban kutatások kiindulópontjaként a szervezeti modell vizsgálatához biztosítanak fontos iránymutatást (Teitel, 2004).

A Szakmai Fejlesztő Iskola létrehozásához bizonyos feltételeknek kell eleget tenni. Mivel szervezeti modellről van szó, így nem szereplőinek egyéni fejlődése szempontjából kívánja a pedagógusok munkáját és így az oktatás színvonalát javítani, hanem a képzőhely és a gyakorlóhely mint egységes szervezet biztosít belső működési mechanizmusai által fejlesztési és fejlődési lehetőséget. Nagyon fontos alapelv, hogy még mielőtt a tényleges és felelősségteljes együttműködés létrejönne, megelőzze azt a képző- és a gyakorló hely valamilyen szintű kapcsolata.

Kiemelt szerephez jut a folyamatos kutatás, amely által fény derülhet a diákok valódi tanulási szükségleteire, e szükségletek kielégítéséhez a hallgatók professzionális felkészítésére és a felkészítéshez szükséges stratégia kidolgozására (Shen, 1993; Falus, 2002). A kutatás a hallgatók és az oktatók (partnerintézmények pedagógusai is) feladata. A folyamat kiindulópontja a tanulói szükségletek ismerete. Ennek kell alárendelni a képzést és az oktatók szakmai fejlesztését, vagyis a hallgatók felkészítését a pedagógus szakmára és az oktatók továbbképzését. Másképpen fogalmazva a képzési, továbbképzési tervek nem külső tényezők által meghatározottak, hanem az adott iskola tanulóinak igényei kell, hogy alakítsák azokat. A Szakmai Fejlesztő Iskola a valódi élet kihívásit veszi alapul, vagyis az egyetemen a hallgatók megtanulják, hogy mit kell tanítaniuk, valamint a tanítás alapjait, a partner intézményben megtanulják, hogy hogyan kell tanítaniuk. A gyakorlóhely a "learning by doing” elv alapján biztosítja a szakmai tapasztalatot, mint tanulási lehetőséget (Pennsylvania State University).

A modellen belül elengedhetetlen bizonyos szervezeti határok átlépése. A Szakmai Fejlesztő Iskola központi elve, azaz a képzőhely és a partner intézmények közös felelőssége a diákok tanulásáért, a hallgatók szakmai felkészítéséért és az oktatók szakmai fejlődéséért szükségessé teszi a merev szervezeti struktúrák át- 
alakítását, új rugalmas struktúrák kialakítását és azon belül új szerepek létrehozását (Romerdahl - Gehrke, 1993 idézi Kotschy, 2003).

A partnerintézmények és a képzőhelyek nem alá-fölérendeltségi viszonyban vannak egymással, hanem egyenrangúak. A hallgatók, pontosabban a tanárjelöltek a gyakorlóhelyeken a tudásuknak megfelelő szintű feladatokat ellátva mint kollégák vannak jelen és nem mint diákok. Mindezen elvek megvalósulásához nagyon fontos az erőforrások (pénzügyi, időbeli, személyzeti) rugalmas, az igényekhez igazitott felhasználása.

Az előbb említett pedagógus-tanárjelölt viszonyon kívül a szervezeti modell más szinteken is az egyenrangú viszony kialakítását jelenti. Egyrészt ez jelen van a képzőhely vezetése és a partner intézmények vezetése, illetve fenntartója kapcsolatában, másrészt jelenti az adott intézmény és partnereinek (iskolai körzet, szakszervezet, szakmai szervezet) egyenrangú viszonyát (Krist - White - Whitelaw, 2016).

A szakmai fejlődés egy kiterjesztett tanulóközösség keretein belül valósulhat meg (Darling-Hammond, 1994). A tanulóközösség tagjai nem csak a képzőhely és a gyakorlóhely oktatói, pedagógusai, hanem más, külső oktatók, valamint a szülők is, akik nagyon hasznos tudást biztosítanak gyermekeikről az oktatók, a pedagógusok és a tanárjelöltek számára.

A Szakmai Fejlesztő Iskola, mint szervezeti modell fontos szerepet tölthet be bizonyos iskolai, tantervi reformok megvalósításában, tantervek implementálásában. Mindezek által pedig, mivel kutatásalapú modellről van szó, hozzájárulhat a regionális vagy nemzeti oktatáspolitika továbbfejlesztéséhez (Pennsylvania State University).

A modell nevelési, oktatási filozófiája a konstruktivista tanuláselmélet, melynek egyik meghatározó eleme a diákok előzetes tudásának, tanulási szükségleteinek felmérése. Ez szembemegy a hagyományos európai gyökerekkel bíró „minden diákot egy szempont alapján mérni” szemlélettel (Abdal-Haqq, 1998. 35. o.). A másik nagyon fontos elv a kooperatív tanulás lehetőségeinek széleskörű kiaknázása, a munkáltatás, a történetolvasás és írás, a felfedezéses tanulás, melyek az önálló tanulás készségeit fejlesztik (Davis, 1999). A szervezési módok közül nagy hangsúlyt fektetnek a kiscsoportos munkaformára, melyet a pedagógusok mint facilitátorok segítenek. A lemaradó tanulók támogatásához elengedhetetlen az egyéni és csoportos felzárkóztatás. Lehetőség van arra, hogy miközben az órai munkát a tanár irányítja, szervezi, közben a hallgatók egyénileg foglalkozhatnak a tanulókkal, 
vagy azok kis csoportjával, ezzel elősegítve, hogy a tanár gyorsabban haladjon a tananyag feldolgozásával (Pritchard - Ancess, 1999). Kiemelt szerephez jut a méltányosság, azaz a családi, szociális, vagy etnikai háttérből adódó különbségek maximális figyelembevétele. Mindehhez elengedhetetlen a hallgató érzékenyitése, valamint ösztönzése arra, hogy ne hátrányként, hanem előnyként értelmezzék a különbözőségeket, merjenek bátran támaszkodni az adott közösség vagy család humán erőforrásaira (Fountain, 1997).

A szervezeti modell sikeres müködtetéséhez elengedhetetlen a családok, a szülők bevonása, aminek nagyon sokféle változata van a szülők iskolai élettel kapcsolatos véleményének a kikérésétől, a tanórán kívüli tevékenységekbe való részvételen keresztül a vasárnapi iskoláig, ahol a szülők egymásnak és a diákoknak nyújtanak segítséget például az angol nyelv tanulásában (Clark, 1999; Schwartz Wendy, 2001).

\section{A részkutatás bemutatása}

A Szakmai Fejlesztő Iskola elvárásainak bemutatása után a továbbiakban vizsgálatunk ismertetésével folytatjuk tanulmányukat. Kutatásunk tárgya az Eszterházy Károly Egyetem gyakorlóiskolájában végbemenő szakmai önfejlesztés, pontosabban a szakmai önfejlesztésre vonatkozó pedagógusi, tanulói, szülői, oktatói és hallgatói nézetek. A kutatás céljaiként fogalmaztuk meg:

- az iskolában dolgozó pedagógusok, gyakorló hallgatók és oktatók nézeteinek feltárását arra vonatkozóan, hogy az iskola milyen lehetőségeket biztosít számukra a folyamatos szakmai fejlődéshez, és hogy ezek a lehetőségek mennyiben javítják a szakmai munka hatékonyságát;

- a tanulók és a szüleik nézeteinek feltárását arra vonatkozóan, hogy menynyire tartják fontosnak, hogy a pedagógusok (beleértve a hallgatókat is), naprakész szakmai ismeretekkel rendelkezzenek, valamint azt alkotó módon alkalmazzák a hétköznapi gyakorlatban, hogyan ítélik meg ők, mint „felhasználók” az iskola önfejlesztő tevékenységét;

- választ kapjunk arra a kérdésre, hogy hogyan lehetne továbbfejleszteni a magyar pedagógusképzést a szakmai önfejlesztés vonatkozásában.

\section{A kutatás hipotézisei}

- H1: A pedagógusok nézetei szerint az iskolavezetés nagy hangsúlyt helyez a pedagógusok szakmai tudásának tervszerủ és tudatos fejlesztésére, 
mindez saját nézeteikben úgy tükröződik, hogy ők maguk is a magas szintű szakmai tudást tartják az iskola fejlődése szempontjából a legfontosabbnak.

- H2: A gyakorlóiskolai pedagógusok saját szakmai tudásszintjének megítélése jelentős összefüggésben van a pedagógusok tudásmegosztásban való részvételének az arányával.

- H3: A gyakorlóiskola fejlesztő iskolává válásában a pedagógusok fontosnak tartják az egyetemmel közösen végzett kutatásokat, és ez a ténylegesen a kutatásokba bekapcsolódó pedagógusok számában is tükröződik.

- H4: A gyakorlóiskolai pedagógusok magas szintủ szakmai tudása és a pálya iránti elkötelezettsége hat a hallgatók nézeteire.

- H5: A pedagógusok törekszenek a tanárjelöltek bevonására az iskola szakmai önfejlesztő tevékenységébe elhivatottságuk növelése érdekében.

- H6: A szülők iskolával szemben megfogalmazott elvárásaiban fontos szerepet kap a pedagógusok folyamatos szakmai fejlődése, ami gyermekeik fejlődésének alapvető feltétele. Ennek alapján értékelik az iskola eredményességét.

- H7: A pedagógusok szakmai fejlődése tetten érhető a diákok nézeteiben, mindez erősíti a tanulásuk hatékonyságát.

Kutatásunk eredményeinek bemutatásához először is ismertetjük azt a logikai vázat, amely mentén az adatok feldolgozása megtörtént. A szakmai fejlődés dimenzióit az iskolavezetés, a pedagógus, a tudásmegosztás, az egyetem és a gyakorlóiskola, a szülók és a gyakorlóiskola, végül pedig a diákok és a gyakorlóiskola vonatkozásában írjuk le. Fontos, hogy minden résztvevő nézeteit megismerjük a szakmaiság tekintetében. Természetesen minden érdekelt fél más és más miatt tartja fontosnak a szakmaiságot. Így kutatásunkkal rávilágíthatunk a nézőpontok eltérő voltára, és árnyaltabb tanulságokat fogalmazhatunk meg a jövőre vonatkozó elképzelésekkel kapcsolatban.

\section{A szakmai fejlödés dimenziói és az iskolavezetés}

E részterület esetében fontosnak tartottuk megvizsgálni, hogy a pedagógusok szerint a szakmai fejlesztés milyen részterületeit tartja az iskolavezetés kiemelten jelentősnek, mekkora a vezetés által preferált területek és a pedagógusok fejlesztési igényei között a lefedettség. Másrészt, észlelik-e a pedagógusok az iskolavezetés tervszerủ és tudatos tevékenységét a szakmai fejlesztés vonatkozásában, milyen 
mértékben, és hogy a jövőt illetően a Szakmai Fejlesztő Iskolává váláshoz szerintük, milyen területeken szükséges a továbblépés.

A pedagógusok szerint az iskolavezetés több részterületen is jelentőséget tulajdonít a szakmai fejlődésnek, fejlesztésnek. A kiválasztott három legfontosabb terület átlagai és szórásuk láthatók az 1. táblázatban:

\begin{tabular}{l|cc}
\hline $\begin{array}{c}\text { Véleménye szerint az iskola mely területeken tartja a legfontosabbnak a } \\
\text { pedagógusi szakmai fejlódését? }\end{array}$ & & \\
\multicolumn{1}{c}{$\begin{array}{c}\text { Kérjük, válasszon ki az alábbi listából legfeljebb három területet, } \\
\text { amelyek Ön szerint fontosak az iskola számára! } \\
\mathrm{N}=102\end{array}$} & átlag & szórás \\
\hline $\begin{array}{l}\text { a pedagógus módszertani tudásának fejlesztése } \\
\text { tanulók kompetenciáinak fejlesztése }\end{array}$ & 0,52 & \\
tehetséggondozás fejlesztése & 0,50 & 0,502 \\
a pedagógus IKT-kompetenciájának fejlesztése & 0,47 & 0,502 \\
a tanulók tanulmányi teljesítményének fejlesztése & 0,35 & 0,480 \\
& 0,32 & 0,470
\end{tabular}

1. táblázat: A szakmai fejlődés preferált területei az iskolavezetés által

A vezetés által leginkább preferált szakmai területek a módszertani tudás, az IKT-kompetencia fejlesztése és a tehetséggondozás fejlesztése. Az összes megjelölt kategória rangsorában a módszertani fejlesztés az első, az IKT-kompetencia a negyedik a szakmai előmenetel pedig a hatodik helyen került megnevezésre. A szakmai fejlődés szempontjából nélkülözhetetlen reflektív tanítás fejlesztését és a helyi kutatásokra való felkészítést a 17 kategóriából a tizenharmadik helyre sorolták a pedagógusok.

Az iskolavezetés által fontosnak tartott területeket összehasonlítottuk a pedagógusok fejlesztési igényeivel és a megvalósult továbbképzések tartalmával (Véleménye szerint az iskola mely területeken tartja a legfontosabbnak a pedagógusi szakmai fejlődését? Jelenleg mely területeken tartja a leginkább szükségesnek a saját szakmai fejlődését? 


\begin{tabular}{|c|c|c|c|c|c|c|}
\hline $\begin{array}{l}\text { A szakmai } \\
\text { fejlesztés } \\
\text { kategóriáinak } \\
\text { rangsora }\end{array}$ & $\begin{array}{c}\text { Az iskolavezetés által } \\
\text { fontosnak tartott szakmai } \\
\text { fejlesztési területek } \\
N=102\end{array}$ & $\begin{array}{c}\text { átlag } \\
\text { (a három } \\
\text { legfontosabb } \\
\text { terület) }\end{array}$ & $\begin{array}{c}\text { A pedagógusok } \\
\text { fejlesztési igényei } \\
\qquad N=102\end{array}$ & $\begin{array}{c}\text { átlag } \\
\text { (a kiválasztott } \\
\text { több válasz) }\end{array}$ & $\begin{array}{l}\text { A megvalósult } \\
\text { továbbképzések } \\
\text { tartalma }\end{array}$ & $\begin{array}{c}A \\
\text { továbbképzéseken } \\
\text { résztvevők (fó) }\end{array}$ \\
\hline 1. & $\begin{array}{l}\text { a pedagógusok módszerta- } \\
\text { ni tudásának fejlesztése }\end{array}$ & 52 & $\begin{array}{l}\text { a pedagógusok IKT- } \\
\text { kompetenciáinak fej- } \\
\text { lesztése }\end{array}$ & 44 & $\begin{array}{l}\text { egészséges életmódra } \\
\text { nevelés }\end{array}$ & 97 \\
\hline 2. & $\begin{array}{l}\text { a pedagógusok IKT-kom- } \\
\text { petenciájának fejlesztése }\end{array}$ & 35 & $\begin{array}{l}\text { különleges bánásmó- } \\
\text { dot igénylő tanulók } \\
\text { fejlődésének támoga- } \\
\text { tása }\end{array}$ & 41 & $\begin{array}{l}\text { neveléssel kapcsola- } \\
\text { tos módszertan }\end{array}$ & 59 \\
\hline 3. & $\begin{array}{l}\text { a pedagógusok szakmai } \\
\text { előmenetelének segítése }\end{array}$ & 27 & $\begin{array}{l}\text { szakmódszertani tu- } \\
\text { dás }\end{array}$ & 33 & szaktárgyi tudás & 40 \\
\hline 4. & $\begin{array}{l}\text { a pedagógus diszciplináris } \\
\text { tudásának fejlesztése }\end{array}$ & 9 & $\begin{array}{l}\text { nevelést segítő mód- } \\
\text { szertani tudás }\end{array}$ & 33 & $\begin{array}{l}\text { IKT-kompetenciák } \\
\text { fejlesztése }\end{array}$ & 31 \\
\hline 5. & $\begin{array}{l}\text { a pedagógusok reflektív } \\
\text { tanításának fejlesztése }\end{array}$ & 7 & $\begin{array}{l}\text { idegen nyelvi kompe- } \\
\text { tencia }\end{array}$ & 26 & tehetségfejlesztés & 30 \\
\hline 6. & $\begin{array}{l}\text { a pedagógusok felkészíté- } \\
\text { se helyi kutatásokra }\end{array}$ & 7 & $\begin{array}{l}\text { általános pedagógiai } \\
\text { és pszichológiai tudás }\end{array}$ & 17 & $\begin{array}{l}\text { társas kapcsolatok } \\
\text { fejlesztése }\end{array}$ & 18 \\
\hline
\end{tabular}


Adatainkból jól látható (2. táblázat), hogy az iskolavezetés prioritásai és a pedagógusok fejlesztési igényei részben fedik egymást. Igaz, az első három helyen található mindkét csoportnál a pedagógusok módszertani és IKT-kompetenciáinak fejlesztése, az iskolavezetésnél azonban hangsúlyosabban jelenik meg a szakmai előmenetel támogatása vagy az ötödik és a hatodik helyen megnevezett reflektivitás fejlesztése és a helyi kutatásokra való felkészítés, ezzel szélesebb spektrumot adva az iskola és a pedagógusok szakmai fejlődésének. A pedagógusoknál a módszertan a legfontosabb fejlesztési igény, legyen szó szakmódszertanról, a különleges bánásmódot igénylő gyermekek fejlesztéséről vagy általában a neveléssel kapcsolatos módszerekről. A tényleges továbbképzések tartalma esetében aránytalanul hangsúlyosan jelenik meg az egészséges életmódra nevelés. Bár azt követően a továbbképzések tartalma inkább a pedagógusok fejlesztési igényekhez látszik igazod$n i$.

Adataink alátámasztják, hogy a gyakorlóban a pedagógusok többsége észleli a vezetőség tudatos tevékenységét a szakmai fejlesztés vonatkozásában. 69\%-uk tisztában van azzal, hogy az iskolának hosszabb távú (legalább 3 éves) továbbképzési terve van. 3\%-uk szerint ilyen nincs, és $28 \%$-uk nem tud róla. (Tudomása szerint létezik-e az iskolának hosszabb távú [legalább 3 éves] továbbképzési terve?, 3. aktív pedagógus kérdőív 2.). Érdekelt bennünket, hogy a pedagógusok mennyire elégedettek az iskolavezetés munkájával a tervezettség, a szervezettség, az ellenőrzés-visszacsatolás és az új kezdeményezések felkarolása vonatkozásában. Mindezek a tulajdonságok a tudatos és felelős vezetői magatartás jellemzői (Kérjük, határozza meg, hogy Ön mennyire elégedett az iskolavezetés munkájával az alábbi területeken!, 2. aktív pedagógus kérdőív 3/1. 2. 3. és 8., és Véleménye szerint az iskola mely területeken tartja a legfontosabbnak a pedagógusai szakmai fejlődését?, 3. aktív pedagógus kérdőív 3/ 3. 4. 9. 15. és 16). 
Pedagógusképzés • 18(46), 2019/1-2.

\begin{tabular}{|c|c|c|c|c|c|}
\hline \multirow{2}{*}{$\begin{array}{c}\text { Az iskolavezetés által } \\
\text { preferált fejlesztési } \\
\text { területek } \\
\text { kategóriák } \\
N=113\end{array}$} & \multicolumn{5}{|c|}{$\begin{array}{l}\text { A pedagógusok elégedettsége az iskolavezetés munkájával } \\
\text { (tervezettség, szervezettség, ellenőrzés visszacsatolás, új } \\
\text { kezdeményezések felkarolása)/gyakoriságok (fó) }\end{array}$} \\
\hline & $\begin{array}{c}\text { nem } \\
\text { elégedett }\end{array}$ & $\begin{array}{l}\text { inkább } \\
\text { nem } \\
\text { elégedett }\end{array}$ & $\begin{array}{l}\text { elégedett is } \\
\text { meg nem is }\end{array}$ & $\begin{array}{l}\text { inkább } \\
\text { elégedett }\end{array}$ & $\begin{array}{l}\text { nagyon } \\
\text { elégedett }\end{array}$ \\
\hline $\begin{array}{l}\text { pedagógusok } \\
\text { diszciplináris tudásának } \\
\text { fejlesztése }\end{array}$ & 0 & 0 & 4 & 5 & 4 \\
\hline $\begin{array}{l}\text { pedagógusok módszertani } \\
\text { tudásának fejlesztése }\end{array}$ & 0 & 0 & 32 & 35 & 21 \\
\hline $\begin{array}{l}\text { pedagógusok szakmai } \\
\text { előmenetelének segítése }\end{array}$ & 0 & 0 & 17 & 19 & 13 \\
\hline $\begin{array}{l}\text { pedagógusok felkészítése } \\
\text { helyi kutatásokban való } \\
\text { közreműködésre } \\
\text { pedagógusok IKT- } \\
\text { kompetenciáinak } \\
\text { fejlesztése }\end{array}$ & 0 & 0 & 21 & 24 & 13 \\
\hline
\end{tabular}

A 3. táblázat értelmezéséhez szükséges megjegyeznünk, hogy a pedagógusok elégedettségének az iskolavezetés munkájával kérdéskörnek több változója volt. A táblázat csak azokat az adatokat tartalmazza, amelyeknél a négy változóval leírt (tervezettség, szervezettség, ellenőrzés-visszacsatolás, új kezdeményezések felkarolása) vezetői tudatosság a pedagógusok szerint együttesen érvényesül a felsorolt kategóriákban. Így a nem elégedettek itt most nem jelennek meg.

A pedagógusok elsősorban, a saját módszertani tudásuk fejlesztése vonatkozásában érzik az iskolavezetés tudatosságát és felelős, átgondolt tevékenységét (56 megemlítés inkább és nagyon elégedett). Ezt követi a pedagógusok IKT-kompetenciáinak fejlesztése (37), majd a szakmai előmenetel támogatása (32). A másik oldalon viszont látható, hogy arányaiban viszonylag sokan gondolják, hogy a tudatosság nem mindig érvényesül ugyanezeken a területeken, erre utal az elégedett és a nem válaszolók viszonylag magas aránya. Kevesen jelölték be a diszciplináris tudás fejlesztését és a helyi kutatásokban való részvételre való felkészítést. Mindez azzal magyarázható, hogy a pedagógusok nem tulajdonítanak akkora jelentőséget a két területnek.

Kutatásunkban nem csak a jelenre koncentráltunk, hanem az iskola jövőbeli szakmai fejlesztési céljaira is. Nyílt kérdéssel kerestük a választ arra, hogy, a pe- 
dagógusok szerint mikor válhat a gyakorlóiskola Szakmai Fejlesztő Iskolává (3. aktív pedagógus kérdőív 10.).

\begin{tabular}{l|c}
\hline $\begin{array}{c}\text { Kérjük, fejezze be az alábbi mondatot azzal a gondolatával, amelyet } \\
\text { a legtalálóbbnak tart! A jó gyakorlóiskola akkor válhat szakmai } \\
\text { fejlesztó iskolává, ha... } \\
\text { kategória csoportok } \\
\mathrm{N}=102\end{array}$ & gyakoriság (fö) \\
\hline $\begin{array}{l}\text { magas szakmai tudás } \\
\text { pedagógusok szakmai fejlődése, elkötelezettség }\end{array}$ & 41 \\
$\begin{array}{l}\text { tudásátadás, megosztás, egymással és más iskolákkal } \\
\text { együttmüködés az egyetemmel }\end{array}$ & 31 \\
hallgatók támogatása & 13 \\
szakmai autonómia & 8 \\
\multicolumn{2}{c}{ 4. táblázat: A pedagógusok által fontosnak tartott tényezők a szakmai fejlesztő iskolává } \\
\multicolumn{2}{c}{ váláshoz }
\end{tabular}

Az összes válaszadó 181 választ adott a kérdésre. Ezekből 21 nagyobb kategóriát alakítottunk ki, majd megvizsgáltuk az egyes kategóriákon belül a megemlítések számát. A fenti táblázatban (4. táblázat) csak a szakmai fejlesztés kategóriáit foglaltuk össze. A pedagógusok a magas szintű szakmai tudást a legelső helyre so rolták (23\%). A szakmai fejlődés szempontjából ezen kívül a fejlődésre való igényt és elkötelezettséget és az egymás közötti és más iskolákkal, intézményekkel való tudásmegosztást tartják a Szakmai Fejlesztő Iskola legfontosabb ismérveinek. A válaszadók közül igen kevesen nevezték meg az egyetemmel való együttműködést és a hallgatók támogatását. Ezekből az adatokból azt a következtetést vontuk le, hogy a pedagógusok elsősorban saját magas szintű szakmaiságukat tartják mind a gyakorlóiskola, mind pedig a Szakmai Fejlesztő Iskola legfontosabb ismérvének. Megkockáztatjuk azt a kijelentést, hogy ez a szakmaiság elsősorban az iskolában tanuló gyermekek igényeinek ismeretét és a gyerekek nevelésével kapcsolatos szakmai tudást jelenti. Az egyetemmel együtt történő tanárképzés, azaz a jövő pedagógusainak támogatása nem megahatározó szakmai fejlesztési cél számukra. Ez egybecseng a 2. táblázat adatai alapján megfogalmazott következtetéseinkkel.

Az első hipotézisünk (H1), amely szerint a pedagógusok nézetei szerint az iskolavezetés nagy hangsúlyt helyez a pedagógusok szakmai tudásának tervszerú és tudatos fejlesztésre, mindez saját nézeteikben úgy tükröződik, hogy ők maguk is a magas szintű szakmai tudást tartják az iskola fejlődése szempontjából a legfonto- 
sabbnak, alátámasztásra került. Ugyanakkor meg kell jegyeznünk, hogy bizonyos jellemzők, amelyek a Szakmai Fejlesztő Iskola fontos ismérvei, nem jelennek meg sem az iskolavezetés, sem pedig a pedagógusok nézeteiben kiemelt helyen. Ilyenek például az iskolavezetőknél a tanárjelöltek szakmai fejlődésének támogatása (7. hely), a pedagógusok reflektív tanításának a fejlesztése (13. hely), pedagógusok felkészítése helyi kutatásokra (13. hely), a pedagógusoknál pedig a mentorálás (6. hely) vagy a kutatásmódszertani tudás (7. hely).

\section{A szakmai fejlödés és a pedagógus}

Kutatásunk e pontján fontosnak tartottuk, hogy a pedagógusok önmagukra vonatkozó nézeteit is megvizsgáljuk a szakmai fejlődés kontextusában, vagyis hogy milyen az önértékelésük e kérdéskörben: miben tartják önmagukat kiemelkedően jónak, melyek a fejlesztendő területek, milyen módon fejlesztik önmagukat, vannak-e a kérdéskörben kifejezetten a „gyakorlós” pedagógusokra jellemző tulajdonságok, általuk preferált fejlesztési területek, rájuk jellemző fejlesztési módok, vagy az önfejlesztésüket elősegítő speciális körülmények.

Először is, arra voltunk kíváncsiak, hogyan értékelik saját magukat a pedagógusok a szakmai tudás és önfejlesztés vonatkozásában (Kérjük, értékelje az alábbi állításokat a szerint, hogy azok mennyire jellemzőek Önre szakmai tevékenysége során?, 2. pedagógus kérdőív 8.). A válaszadók egy 5 fokozatú skálán jelölték válaszaikat. A gyakorlós pedagógusok jelentős többsége kiválónak ítéli meg szakmai tudását $(92,21 \%)$ és folyamatosan keresi a megújulás lehetőségeit $(85,8 \%)$, elkötelezett a szakmai fejlődés irányában. Több, mint fele $(63,7 \%)$ naprakész az új ismeretek követésében, ugyanakkor a fele osztaná meg tudását (50,4\%), és kevesebb, mint fele tartana bemutató órákat (46,9\%).

Kicsit mélyebbre ásva azt is megnéztük, hogy a fentiekben kijelölt területek esetében van-e a pedagógusok között valamilyen különbség a pályán eltöltött évek, az iskolában való beosztás és a pedagógusfokozat vonatkozásában, ennek érdekében varianciaanalízist végeztünk (ANOVA). Ennek alapján megállapítható, hogy a pedagógusok közül az általános iskolai tanítók gondolják a leginkább úgy, hogy kiváló szaktudással rendelkeznek (Sig. $=0,005<0,05$ ). A szakirodalom követése estében minél hosszabb ideje dolgoznak a gyakorlóban a pedagógusok, annál inkább nyomon követik azt (Sig. $=0,008<0,05)$. Közülük is elsősorban az általános iskola felső tagozatában tanító pedagógusokra (Sig. $=0,007<0,05)$ és a mesterpedagógusokra jellemző a szakirodalmi tájékozottság. A bemutató órák megtartását a 
legszívesebben a mesterpedagógusok (Sig. $=0,001<0,05)$ vállalják. Az általános iskolai tanítók (Sig=0,014<0,05), a középiskolai vezető tanárok (Sig. $=0,051>0,05)$, a szakértő vagy szaktanácsadó tanárok, beosztás szerint pedig a mesterpedagógus fokozatba tartozók (Sig. $=0,015<0,05$ ) azok, akik a leginkább tartanának műhelyfoglalkozásokat (Sig. $=0,01<0,05$ ). Mindez azt jelenti, hogy a magas szintủ szakmai tudás mint szakmai érték elsősorban az pályán hosszabb időt eltöltő általános iskolai tanítók és a középiskolai vezető tanárok körében jellemző, és ők azok is, akik a megszerzett tudásukat hajlandóak megosztani másokkal.

Kézenfekvő volt a kérdés, hogy a pedagógusok a fejlesztés, önfejlesztés mely eszközeivel, módszereivel élnek a leginkább, és azokon belül is milyen hagyományos és új típusú eszközök és módszerek jelennek meg (3. aktív pedagógus kérdőív 4.). A válaszadók több választ is megjelölhettek:

\begin{tabular}{|c|c|c|}
\hline $\begin{array}{c}\text { Ön milyen lehetôségekkel él a továbbképzéseken kívül } \\
\text { szakmai fejlődése érdekében? Kérjük, válasszon az alábbiak } \\
\text { közül! } \\
\text { kategóriák } \\
\mathrm{N}=102\end{array}$ & átlag & szórás \\
\hline szakmai folyóiratokat, könyvet olvas & 0,86 & 0,346 \\
\hline $\begin{array}{l}\text { más tantestületek, szakmai közösségek adatbázisát } \\
\text { használja }\end{array}$ & 0,37 & 0,486 \\
\hline a kollégák óráit látogatja, megbeszélik a tapasztalatokat & 0,31 & 0,466 \\
\hline tantestület szakmai adatbázis & 0,28 & 0,453 \\
\hline az egyetem által szervezett konferenciákra jár & 0,28 & 0,453 \\
\hline szakkönyvtárba jár & 0,27 & 0,448 \\
\hline hazai konferenciákra jár & 0,27 & 0,448 \\
\hline iskolai könyvtárba jár & 0,25 & 0,438 \\
\hline publikál szakmai témákról & 0,07 & 0,254 \\
\hline saját vagy közös tanári weboldalt működtet & 0,05 & 0,217 \\
\hline nemzetközi konferenciákra jár & 0,01 & 0,99 \\
\hline blogot ír & 0 & 0 \\
\hline
\end{tabular}

5. táblázat: A szakmai önfejlesztés pedagógusok által előnyben részesített lehetőségei

A szakirodalom olvasása kimagaslóan a legfontosabb önfejlesztési eszköz (5. táblázat). A válaszadók előszeretettel használják más közösségek adatbázisát, járnak egymás óráit látogatni, élnek az egyetem által szervezett és más hazai konferenciák, mint a tudás megosztás hagyományos lehetőségével. Az új típusú mód- 
szerek, azaz a kutatás útján szerzett tudás publikálása, és az IKT-eszközök felhasználása a tudásmegosztásra csak kevés pedagógusra jellemző.

Külön figyelmet igényelnek a pedagógusok által látogatott továbbképzések. Az erre vonatkozó adatokat dokumentumelemzéssel nyertük. A dokumentumokat az iskolavezetés bocsátotta rendelkezésünkre. A szakirodalom is alátámasztja, hogy a továbbképzések jelentik manapság a pedagógusok körében az egyik legelterjedtebb önfejlesztési módszert a szakirodalom nyomon követése után. Nincs ez másként a gyakorlóiskolában sem.

\begin{tabular}{|c|c|c|c|}
\hline továbbképzések száma & $\begin{array}{c}\text { összes résztvevő } \\
(f o ̛)\end{array}$ & témák száma & $\begin{array}{c}\text { pályázatok keretén } \\
\text { belüli továbbképzések } \\
\text { száma }\end{array}$ \\
\hline 28 & 388 & 15 & 8 \\
\hline
\end{tabular}

Kiemelkedöen magas nem csak a továbbképzések, hanem az azokon résztvevök száma is (6. táblázat). Az egy főre jutó továbbképzések száma a tantestületben (388/132 fő) 2,56. A továbbképzések több, mint egy negyede pályázatok keretén belül valósult meg 2009 óta.

\begin{tabular}{l|cc}
\hline \multicolumn{1}{c|}{ továbbképzések témái } & darab & résztvevők \\
\hline egészséges életmódra nevelés & 6 & 97 \\
neveléssel kapcsolatos módszertani & 4 & 59 \\
szaktárgyi & 3 & 40 \\
IKT-kompetenciák fejlesztése & 2 & 31 \\
tehetségfejlesztés & 3 & 30 \\
társas kapcsolatok fejlesztése & 1 & 18 \\
család pedagógia & 1 & 18 \\
olvasás pedagógia & 1 & 15 \\
népismeret & 1 & 13 \\
honismeret & 1 & 12 \\
környezettudatos magatartás kialakítása & 1 & 12 \\
elsősegélynyújtás & 1 & 12 \\
vezetőképzés & 1 & 11 \\
könyvtár pedagógia & 1 & 10
\end{tabular}


\begin{tabular}{l|cc} 
esélyegyenlőség & 1 & 10 \\
összes & 28 & 388 \\
7. táblázat: A továbbképzések témái és az azokon részt vett pedagógusok száma
\end{tabular}

A továbbképzések témái is igen nagy változatosságot mutatnak (7. táblázat). Kiemelkedő az egészséges életmódra neveléssel kapcsolatos továbbképzések aránya és a képzéseken résztvevők száma. Olyan különleges területek is megjelennek, mint a családpedagógia, olvasás- és könyvtárpedagógia.

A továbbiakban azt vizsgáltuk meg, hogy az elmúlt öt évben a pályázatok mennyiben segítették a pedagógusok szakmai fejlődését (Véleménye szerint milyen hatást gyakorolt a pályázat (tok) megvalósítása a tantestület életére?, 1. aktív pedagógus kérdőív 12). A pedagógusok jelentős többsége számára a pályázatok leginkább szakmai kihívást jelentettek (80\%). A válaszadóknak több mint fele fontosnak tartotta a motivációt az iskolai munkában és a szakmai elómenetelben nyújtott támogatást. A képet árnyalja, hogy $62,8 \%$ úgy ítélte meg, hogy a pályázatok folyamatos túlterhelést jelentettek a tantestület számára, amit ellensúlyozott a szakmai előmenetel támogatása és az anyagi elismertség (72,8\%). Kereszttáblaelemzés segítségével elemeztük a pedagógusok előmeneteli rendszere és a megvalósított pályázatok kapcsolatát. Először is azt néztük meg, hogy kik azok, akik számára elsősorban szakmai kihívást jelentettek a pályázatok. 
Pedagógusképzés • 18(46), 2019/1-2.

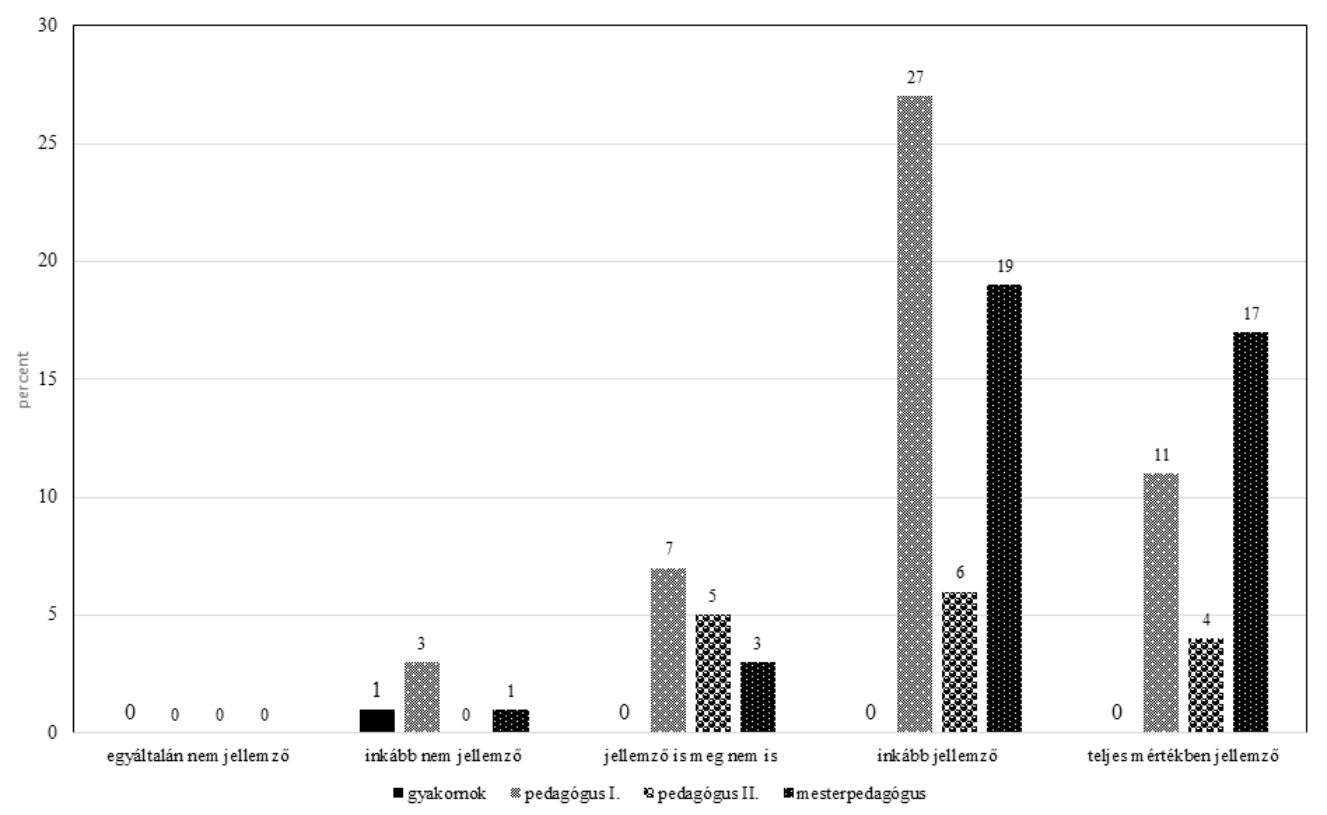

1. ábra: Szakmai kihívás a pedagógusok számára $(\mathrm{N}=125)$

Az ábrából látható (1. ábra), hogy a legtöbben a pedagógus I. (79\%) és a mesterpedagógus $(90 \%)$ kategóriába tartozók élték meg szakmai kihívásként a pályázatokat. A pedagógus II. kategóriába tartozók esetében egyenletes a megoszlás azok között, akik számára a legnagyobb, nagy és kisebb mértékủ kihívást jelentették a pályázatok. 


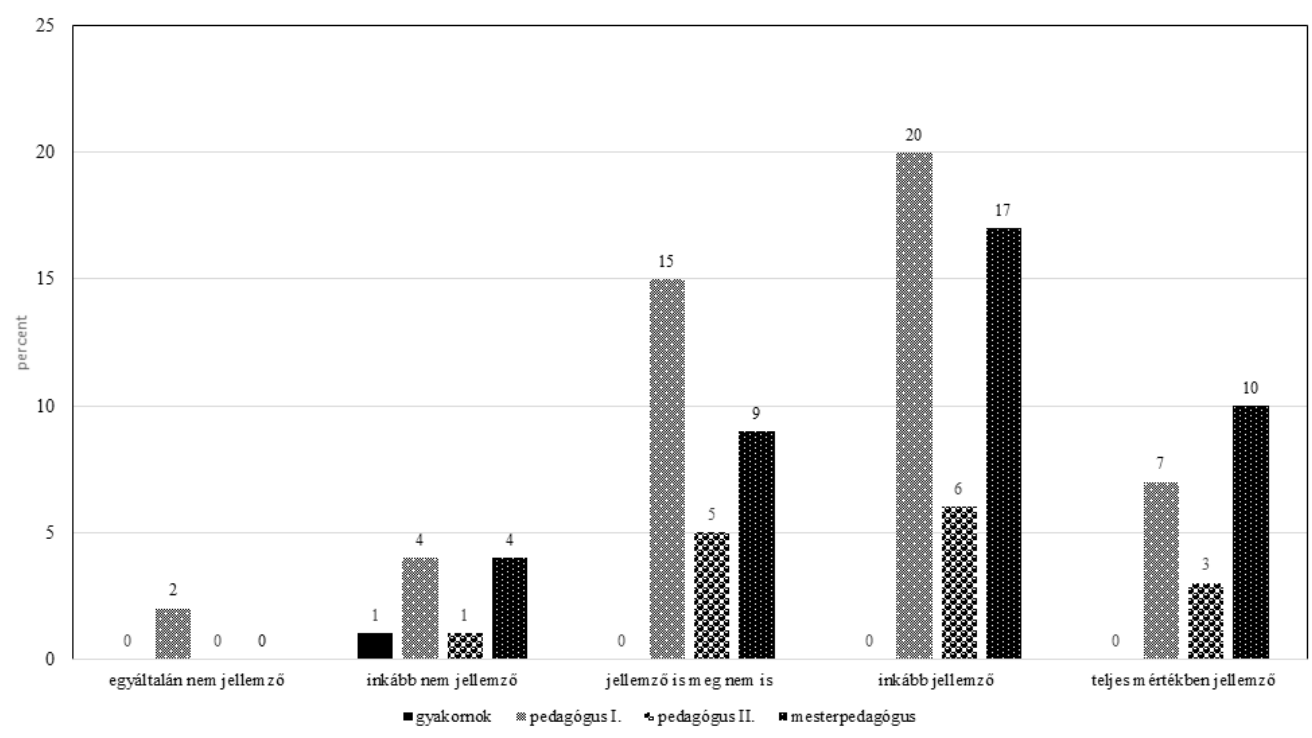

2. ábra: A pályázatok motiváló hatása az iskolai munkára $(\mathrm{N}=125)$

A szakmai kihívással egybecseng, hogy a pályázatok iskolai munkában való motiváló erejének a megítélése vonatkozásában is a pedagógus I. (56\%) és a mesterpedagógus kategóriába tartozók (67,5\%) voltak azok, akik számára leginkább húzó erőt jelentettek, ugyanakkor a pedagógus I. kategóriába tartozóknál érdekes, hogy a válaszadók 31\%-a (15 fö) számára nem volt egyértelmű ez a motiváció (2. ábra).

A szakmai előmenetel támogatása vonatkozásában is érdemes kicsit közelebbről megvizsgálni e kérdést. 
Pedagógusképzés • 18(46), 2019/1-2.

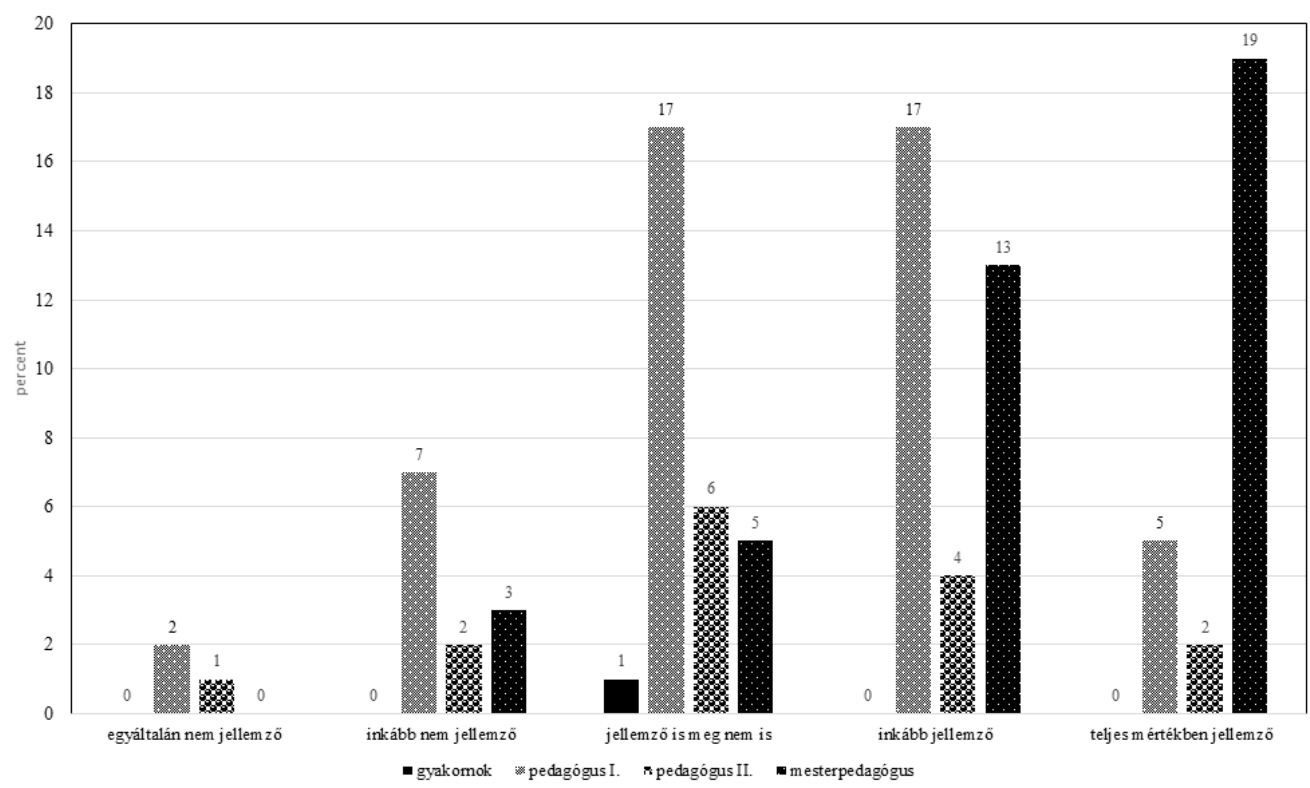

3. ábra: Pályázatok hatása az előmeneteli rendszerre $(\mathrm{N}=125)$

Egyértelműen a mesterpedagógusok azok, akik leginkább úgy vélik, hogy a pályázatok támogatták őket a pedagógus-előmeneteli rendszerben: 40 főből 19 fő $(47,5 \%)$ teljes mértékben jellemzőnek tartják ezt (3. ábra). A pedagógus I., a pedagógus II. és a gyakornoki fokozatba tartozók több, mint fele úgy ítélte meg, hogy jellemző is meg nem is, inkább nem jellemző vagy egyáltalán nem jellemző ez a támogatás. 


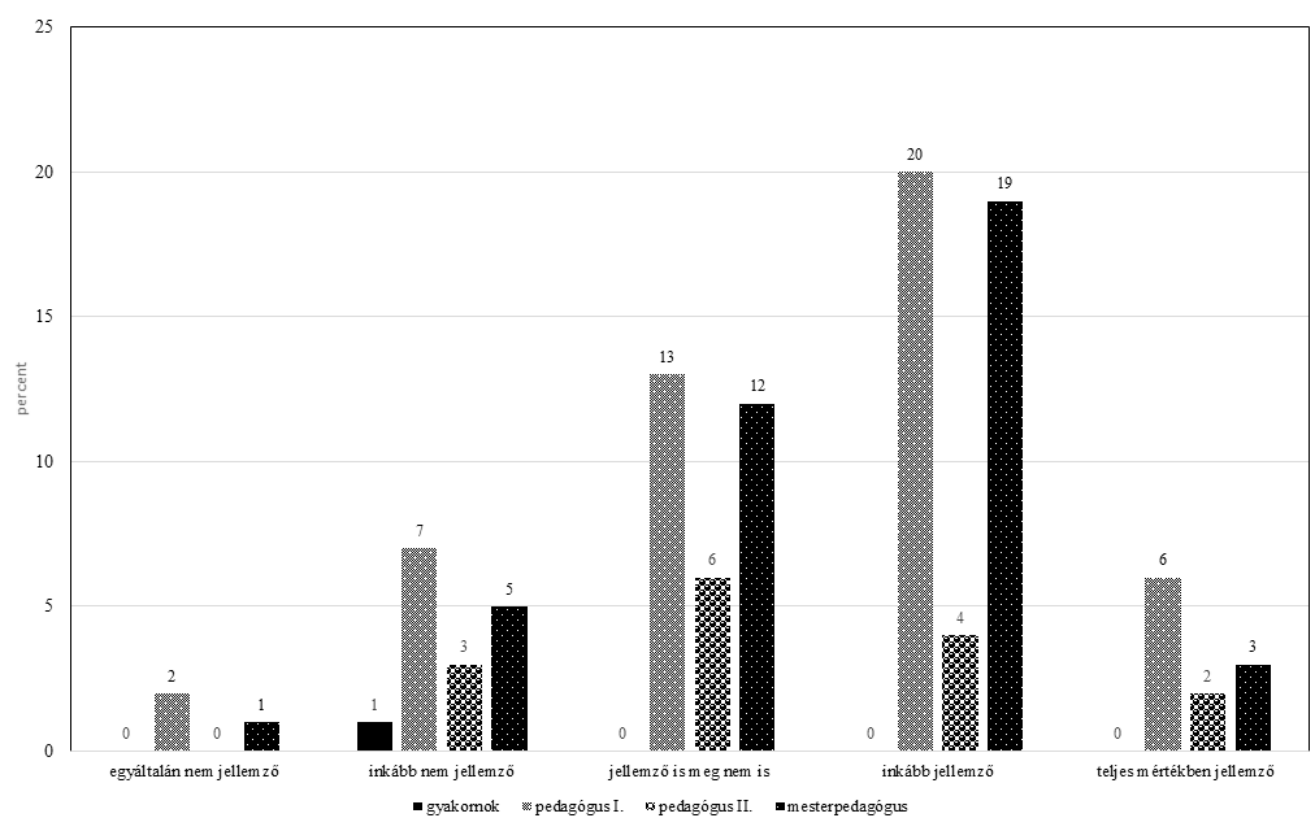

4. ábra: A pályázatok okozta túlterheltség $(\mathrm{N}=125)$

Tovább vizsgálva a pályázatok hatását a pedagógusfokozatok vonatkozásában, a pedagógus I. és a mesterpedagógus kategóriába tartozókat figyelemmel kísérve látható, hogy a mesterpedagógusok 55\%-a (22 fő a 40-ből) inkább jellemzőnek, vagy teljes mértékben jellemzőnek tartotta a túlterheltséget (4. ábra). A pedagógus I. kategóriába tartozóknál ez az arány 54\% (26fő a 48-ból) volt. 


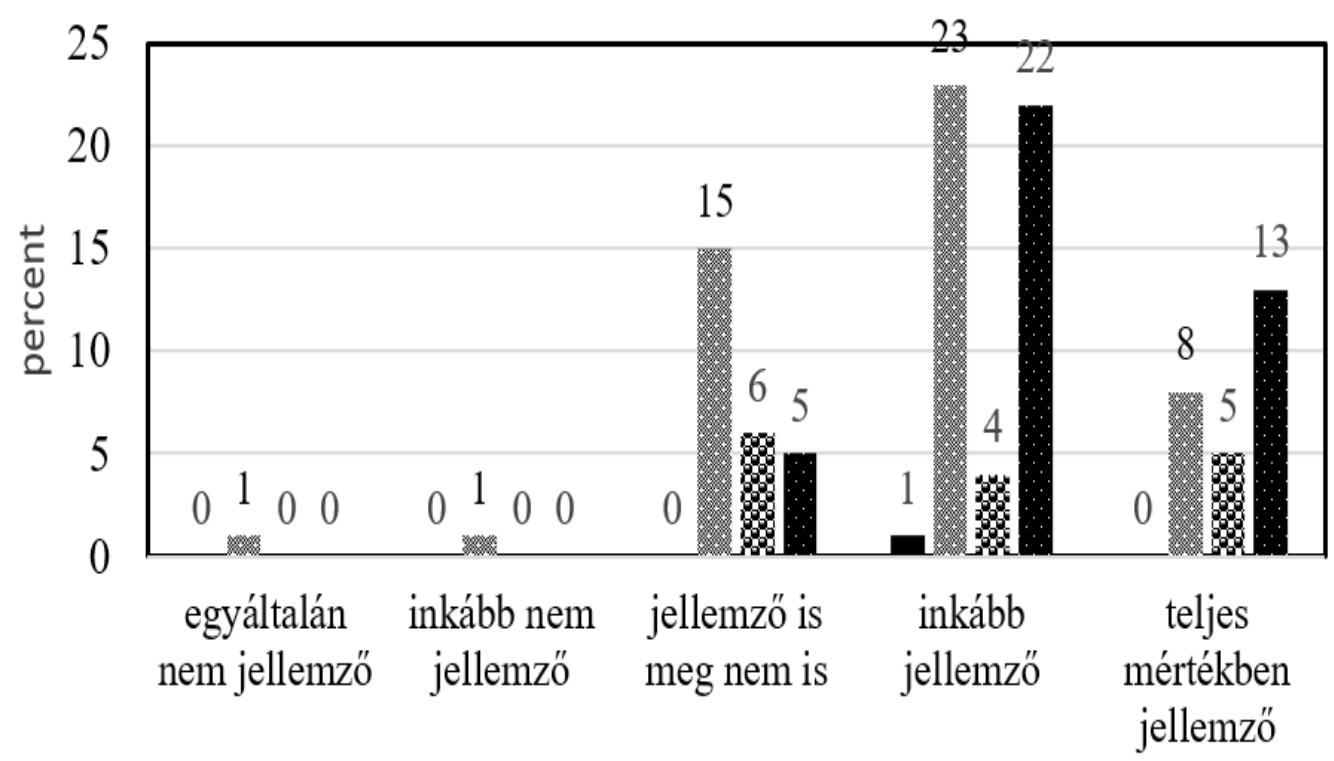

gyakornok pedagógus I. ₹ zagedagógus II. mesterpedagógus 5. ábra: A pályázatok révén megvalósuló anyagi elismertség $(\mathrm{N}=125)$

$\mathrm{Az}$ anyagi elismertség tekintetében egyértelmüen a mesterpedagógusok $(87,5 \%)$ érezték úgy, hogy inkább vagy teljes mértékben támogatták őket a pályázatok (35 fó a 40-ből). A pedagógus I. kategóriába tartozók esetében ez az arány 64,5\% (31 fó a 48-ból) (5. ábra). Még a pedagógus II. kategóriába tartozók is elismerték a pályázatok pozitív hatását az anyagi előrejutás területén, bár arányaikban ők inkább az ingadozók közé tartoznak.

A fenti adatokat elemezve tehát látható, hogy az összes válaszoló pedagógus közül elsősorban a mesterpedagógusok és a pedagógus I. kategóriába tartozók azok, akik a pályázatok kínálta lehetőségekkel a leginkább éltek és belőlük a legtöbbet profitáltak.

\section{A tudásmegosztás mint a pedagógusok számára megfogalmazott szakmai elvárás}

A pedagóguséletpálya-modell és a Szakmai Fejlesztő Iskolák koncepciója is nagyon fontos szakmai elvárásként fogalmazzák meg a tudásmegosztást tantestületen belül, a tantestület és más iskolák vonatkozásában, de nem tekinthetünk el a gyakorlóiskola és az egyetem együttműködésén alapuló tudásmegosztástól sem. Érdemes tehát ennek a kérdésnek egy kicsit több figyelmet szentelnünk. 
Először azt néztük meg, hogy a gyakorlóiskola legfontosabb feladati között mennyire tartják fontosnak a pedagógusok a példamutatást és a pedagógiai fejlesztések, innovációk szakmai disszeminálását (megosztását) más iskolák számára az egész tantestület vonatkozásában, majd leszúkítettük a kört azokra a pedagógusokra, akik az elmúlt 5 évben tartottak valamilyen továbbképzést.

A gyakorlóiskola feladatai közül a példamutatás más iskolák számára 4,55 átlaggal a negyedik a tudásmegosztás, disszeminálás 4,15 átlaggal a tizenegyedik a rangsorban 21 feladat közül, azaz az utóbbi nem tartozik a kiemelten fontos feladatok közé.

A pedagógusok egy része mégis meg kíván felelni a tudásmegosztás szakmai elvárásának. Ők főleg a továbbképzések megtartásából vették ki részüket (3. pedagógus kérdőív 6.). A válaszadók igen és nem válaszok közül választhattak:

\begin{tabular}{l|cc}
\hline $\begin{array}{c}\text { Ön tartott valamilyen szakmai } \\
\text { továbbképzést az elmúlt öt évben? } \\
\text { kategóriák } N=102\end{array}$ & gyakoriság (fö) & százalékos gyakoriság (\%) \\
\hline igen & 66 & 64,7 \\
nem & 36 & 35,3
\end{tabular}

8. táblázat: Az elmúlt öt évben tartott továbbképzések aránya

A válaszadók több, mint fele tartott valamilyen továbbképzést az elmúlt öt évben (8. táblázat). Ez az adat igen nagy aktivitást mutat egy nem gyakorló iskolához képest, de a Szakmai Fejlesztő Iskola megvalósításához ennél is nagyobb aktivitásra lenne szükség, hiszen a kiemelkedően magas színvonalúra értékelt tudás megosztása a modell mủködésének alapfeltétele.

A továbbiakban érdekelt bennünket, hogy a továbbképzéseket tartott kollégáknak milyen az eloszlása pedagógusfokozatok és az iskolában eltöltött évek viszonyában.

\begin{tabular}{|c|c|c|}
\hline kategóriák $N=102$ & gyakoriság (fó) & százalékos gyakoriság (\%) \\
\hline gyakornok & 0 & 0 \\
\hline pedagógus $I$. & 33 & 32,35 \\
\hline pedagógus II. & 6 & 5,8 \\
\hline mesterpedagógus & 9 & 8,8 \\
\hline kutatótanár & 0 & 0 \\
\hline nem válaszolt & 54 & 52,9 \\
\hline összes & 102 & 100 \\
\hline
\end{tabular}


A megkérdezettek közül 54 fó nem jelölte meg, hogy milyen pedagóguskategóriába tartozik (9. táblázat). Ez nagymértékben nehezíti bizonyos tendenciák megállapítását. A válaszadók közül a legtöbben a pedagógus I. kategóriába tartozók vettek részt továbbképzések megtartásában.

Sajnos az iskolában eltöltött évek vonatkozásában nem tudunk következtetéseket megfogalmazni, mivel a beazonosíthatóság miatti félelmükből kifolyólag sokan nem jelölték be (59 fö), hogy mióta dolgoznak a gyakorlóiskolában. A kapott adatok alapján nem vonhatók le a tendenciákra vonatkozó következtetések.

A pedagógusok által tartott továbbképzéseket iskolai dokumentumok elemzése alapján vizsgáltuk, amelyeket az iskola vezetése tett számunkra elérhetővé. A továbbképzéseket lebontottuk témákra, továbbképzési alkalmak számára és a továbbképzések óraszámára. A legtöbb továbbképzést az IKT-kompetenciák (11 alkalom és 449 darab óra), a módszertan (8 alkalom és 2079 darab óra), valamint a szakmai megújulás és előmenetel segítése ( 3 alkalom és 105 darab óra) terén tartották a pedagógusok. A legmagasabb óraszámot egyértelműen a módszertani továbbképzésék jelentették. Ez egybecseng azzal, hogy a pedagógusok nagy hangsúlyt helyeznek a szakmai tudás magas színvonalára. Ebben érzik magukat erősnek, és ezt osztják meg saját tantestületen belül és más iskolák pedagógusaival.

A célcsoportokat tekintve a legtöbb továbbképzés $(19 \mathrm{db})$ általános jellegü, minden pedagógus számára kamatoztatható szakmai tudás átadását túzte célul, ezt követték a középiskolai tanároknak (4 db), a szakvezetőknek (4 db), a szaktanároknak (3 db), majd az általános iskolai tanárok (2 db) szóló képzések.

Elmondható, tehát a továbbképzések széles vertikumában vettek részt a gyakorlóiskola pedagógusai mint képzők. Főleg a módszertani képzés az, amelyet a zászlajukra tűztek, de nem maradtak ki olyan célcsoportok sem, mint az intézményvezetők, óvodapedagógusok vagy éppen a külföldi tanárok.

Az előzőekből tehát jól látható, hogy a pedagógusok magasra értékelik szakmai tudásukat és példaként állítják más iskolák számára. Nagyon sokféleképpen fejlesztik magukat. Kiemelkedő azoknak a továbbképzéseknek a száma, amelyeken részt vettek. A gyakorlóiskola tudásmegosztó szerepének nem tulajdonítanak akkora szerepet, mint a más iskolák számára nyújtott példamutatásnak, és a tudásmegosztásban résztvevő pedagógusok száma is ezt támasztja alá. Nem nyert igazolást tehát második hipotézisünk (H2), amely szerint a gyakorlóiskolai pedagógusok saját szakmai tudásszintjének megitélése jelentős összefüggésben van a pedagógusok tudásmegosztásban való részvételének az arányával. 


\section{Az egyetem és a gyakorlóiskola a szakmai fejlesztés vonatkozásában}

\section{A kutatópedagógus}

Korábban már szóltunk arról, hogy a szakmai fejlődés egyik módja, valamilyen téma alaposabb feltárása, kutatása és az így megszülető tudás megosztása. Az előzőekben már hivatkoztunk a pedagógus-életpályamodellre és a Szakmai Fejlesztő Iskolák elvárásaira. Egy újabb elvárás tehát a kutatás és az általa történő szakmai fejlődés, de nem tekinthetünk el a hallgatók fejlesztésétől, az iskola szakmai megújulásától, nem beszélve az egyetemi oktatók szakmai megújulásáról. Ezért került vizsgálódásunk fókuszába, hogy az iskola eredményessége szempontjából a pedagógusok mennyire tartják fontosnak az egyetemmel való együttmúködést, a pedagógusok részvételét tudományterületi, pedagógiai, pszichológiai kutatásokban, a pedagógusok folyamatos szakmai fejlesztését és a pedagógusok szaktudományos képzését (Véleménye szerint mik a gyakorlóiskola legfontosabb feladatai?, 3. aktív pedagógus kérdőív 1/4. 14. és 15., és Véleménye szerint az alábbi tényezők közül melyek segítik elő a leginkább az iskola eredményességének növelését? 2. aktív pedagógus kérdőív 5/ 13.). A gyakorlóiskola az összesen megnevezett 21 feladatából a pedagógusok folyamatos pedagógiai fejlesztése a 7 . helyen, a pedagógusok szaktudományos képzése a 10. helyen, az egyetemmel való együttmúködés a 14. helyen van. A válaszadók szerint az egyetem és a gyakorlóiskola szoros szakmai együttműködése elsősorban a pedagógusok folyamatos pedagógiai fejlesztése területén biztosíthatja az iskola eredményességét. Jelentős még az egyetemmel való kutatási együttműködés, a pedagógusok szaktudományos képzése és a pedagógusok részvétele pedagógiai és pszichológiai kutatásokban.

Részletesebben is megvizsgáltuk, hogy a gyakorlóiskolai feladatok közül a $k u$ tatásra vonatkozókat mennyire tartják fontosnak az egész tantestületen belül (3. aktív pedagógus kérdőív 1.). A válaszadók egy 5-fokozatú skálán értékelték a megadott válaszokat: 
Pedagógusképzés • 18(46), 2019/1-2.

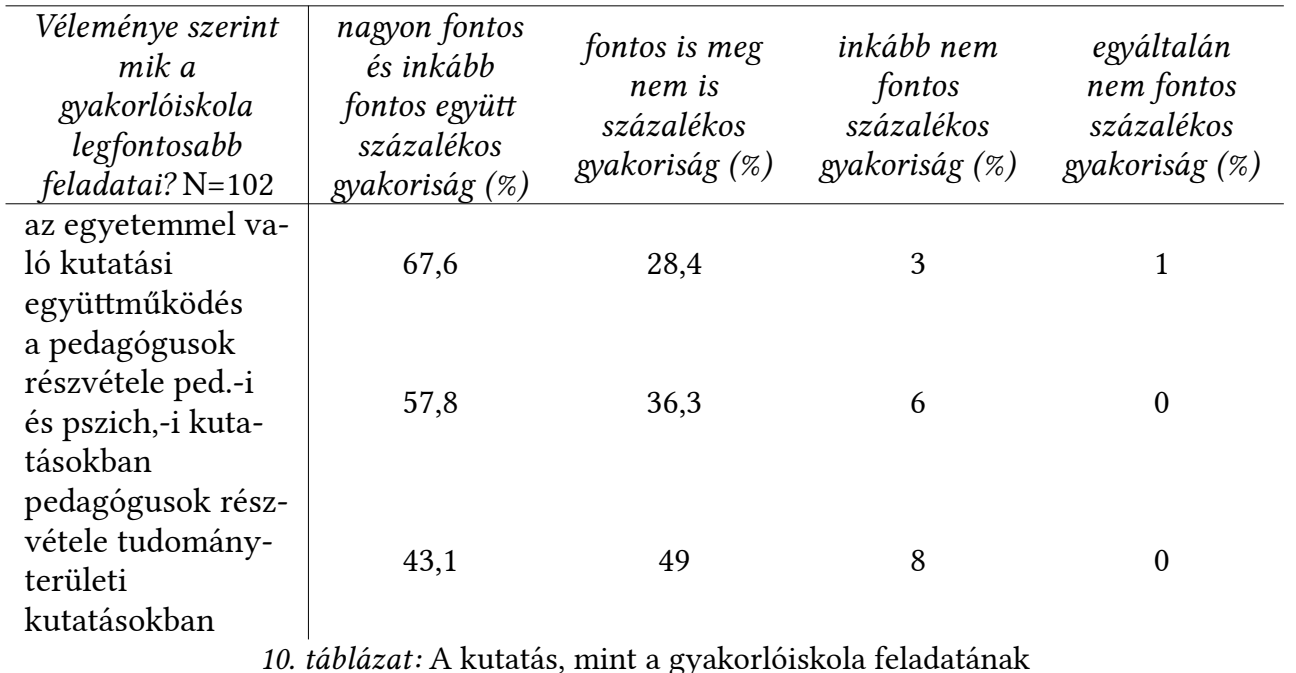

A válaszadók kicsit kevesebb, mint fele mind a három területet fontosnak tartja (10. táblázat). A három kategória vonatkozásában megvizsgáltuk azok arányát is, akik az egyáltalán nem vagy inkább nem válaszokat részesítették előnyben. Az egyáltalán nem válasz csak az egyetemmel való együttműködésnél volt jelen, de ott is csak $1 \%$ tette erre a voksát. Itt az egyáltalán nem és inkább nem fontos válaszok együttes aránya $4 \%$ volt. A pedagógusok pedagógiai és pszichológiai kutatásokban való részvételét $6 \%$, tudományterületi kutatásokba való bekapcsolódást pedig $8 \%$ nem tartotta fontosnak.

Tovább árnyalja a képet, hogy a gyakorlóiskola eredményességének a növeléséhez (2. aktív pedagógus kérdőív 5 . kérdés) a pedagógusok motiváltságát (átlag $0,78)$ és szakmai felkészültségét, képzettségét (átlag 0,72) tartják elsősorban szükségesnek. Az egyetemmel való szoros együttmüködés csak a hetedik a rangsorban (átlag 0,27).

Következtetésképpen az fogalmazhatjuk meg, hogy az iskola fejlődése szempontjából a pedagógusok mindenképpen a saját humánerőforrásuk fejlesztésében hisznek (pedagógiai és szaktudományi tudás). Kevésbé hisznek a kutatások által biztosított szakmai innovációk fontosságában.

A Szakmai Fejlesztő Iskolává váláshoz fontos lenne, hogy a gyakorlóiskola pedagógusai bekapcsolódjanak a helyi, az egyetemmel végzett kutatásokba. (Ön az elmúlt 5 évben bekapcsolódott valamilyen, az iskolában folyó kutatásba?, 3. aktív pedagógus kérdőív 8.). Jelentős többségben vannak a tantestületen belül, akik nem vettek részt kutatásokban (61,8\%). 21,6\% vett részt egy és $16,7 \%$ több kutatás- 
ban. Mivel a kérdőív kitöltői nagyon sokan nem jelölték meg az iskolában eltöltött időt, beosztást és a pedagógus kategóriákat, így nagy ívű következtetéseket nem tudunk levonni arra vonatkozóan, hogy milyenek a csoportok közötti különbségek. A válaszadók közül azonban látható, hogy tipikus tendenciák érvényesülnek, azaz a legtöbb ideje az iskolában dolgozók, a mesterpedagógus fokozatban lévők és a szaktanácsadó vagy szakértő tanárok azok, akik a leginkább bekapcsolódtak valamilyen iskolai kutatásba.

Kicsit több, mint a pedagógusok egyharmada részt vett közös kutatásokban (38,3\%), és ez adat valójában ellentmondásban vannak azokkal, amelyek a kutatás fontosságát mutatják be a pedagógusok szemszögéből a gyakorló életében. Ez azt a következtetést engedi meg számunkra, hogy a kutatásokban való részvételt elsősorban az egyetemi oktatók feladatának tartják a pedagógusok. És hogy menynyire hasznosultak ezek a kutatási eredmények a gyakorló iskola fejlesztésében (3. aktív pedagógus kérdőív 9.)?

\begin{tabular}{l|cc}
\hline $\begin{array}{c}\text { Ön az elmúlt } 5 \text { évben } \\
\text { bekapcsolódott valamilyen, az } \\
\text { iskolában folyó kutatásba? } \\
\text { kategóriák } \\
N=102\end{array}$ & $\begin{array}{c}\text { Ha az elózó kérdésre igennel } \\
\text { válaszolt, véleménye szerint milyen } \\
\text { mértékben sikerült felhasználni a } \\
\text { kutatás eredményeit a gyakorlóiskola } \\
\text { fejlesztéséhez? }\end{array}$ & $\begin{array}{c}\text { százalékos } \\
\text { gyakoriság } \\
(\%)\end{array}$ \\
\hline nem vett részt kutatásokban & 63 & \\
egyáltalán nem sikerült & 4 & 61,8 \\
kis mértékben & 10 & 3,9 \\
közepes mértékben & 16 & 9,8 \\
nagymértékben & 9 & $\mathbf{1 5 , 7}$ \\
\hline összes & 102 & 8,8 \\
\hline \multicolumn{1}{c}{ 11. táblázat: A közös kutatások hasznosságának megítélése }
\end{tabular}

11. táblázat: A közös kutatások hasznosságának megítélése

Látható, hogy a pedagógusok igen megosztottak ezen a téren (11. táblázat). Arányaiban a közepes mértékủ hasznosulás mellett teszik le a legtöbben a voksukat, de nem tekinthetünk el azoktól a véleményektől, amelyek szerint kicsi volt a hasznosulás mértéke, vagy egyáltalán nem hasznosultak az eredmények. Ezt támasztják alá azok az elemzések is, amelyek a háttérváltozók (iskolában eltöltött év, beosztás és fokozat) mentén próbáltak feltárni bizonyos eltéréseket a válaszadók csoportjai között. A közepes mértékủ hasznosulás véleményén elsősorban a 21-30 éve az iskolában dolgozók, a szakértők és szaktanácsadók, és a mesterpedagógus fokozatban lévők vannak. Itt vissza kell térnünk a fejezet elején vizsgált 
kérdéskörre, vagyis az egyetem és a gyakorlóiskola együttmüködése az iskola eredményességének növekedésében a pedagógusok szerint inkább a pedagógusok pedagógiai és szaktudományos tudását hivatott fejleszteni. A közös kutatások eredményeivel kapcsolatban megfogalmazott kételyek itt támasztják alá, hogy az iskola eredményességének a növelésében miért nem tulajdonítanak fontos szerepet a közös kutatásoknak.

Összegzésképpen tehát elmondható, hogy a kutatásokba való bekapcsolódást az iskola Szakmai Fejlesztő Iskolává válásában fontosnak tartják a pedagógusok, mégis inkább az oktatók feladatának tartják azt. Viszonylag kevesen, kicsit több, mint egyharmaduk vett részt ezekben a kutatásokban, az eredmények hasznosulásával kapcsolatban azonban kétségeik vannak. Harmadik hipotézisünk (H3) nem nyert alátámasztást. Bár a gyakorlóiskola fejlesztő iskolává válásában a pedagógusok fontosnak tartják az egyetemmel közösen végzett kutatásokat, ez a ténylegesen a kutatásokba bekapcsolódó pedagógusok számában nem tükröződik.

\section{Az oktatók}

Az oktatók a hallgatók színvonalas felkészítését tartják a legfontosabb gyakorlóiskolai feladatnak (átlag 5). Az egyetemmel való kutatási együttmúködés csak kilencedik a rangsorban (átlag 3,92). A pedagógusok részvétele pedagógiai, pszichológiai témájú kutatásokban (átlag 3,5) és szaktudományi kutatásokban (átlag 3,25) csak ezután kerül megnevezésre (Véleménye szerint mik a gyakorló iskola legfontosabb feladatai? Oktatói kérdőív, 19. kérdés). 


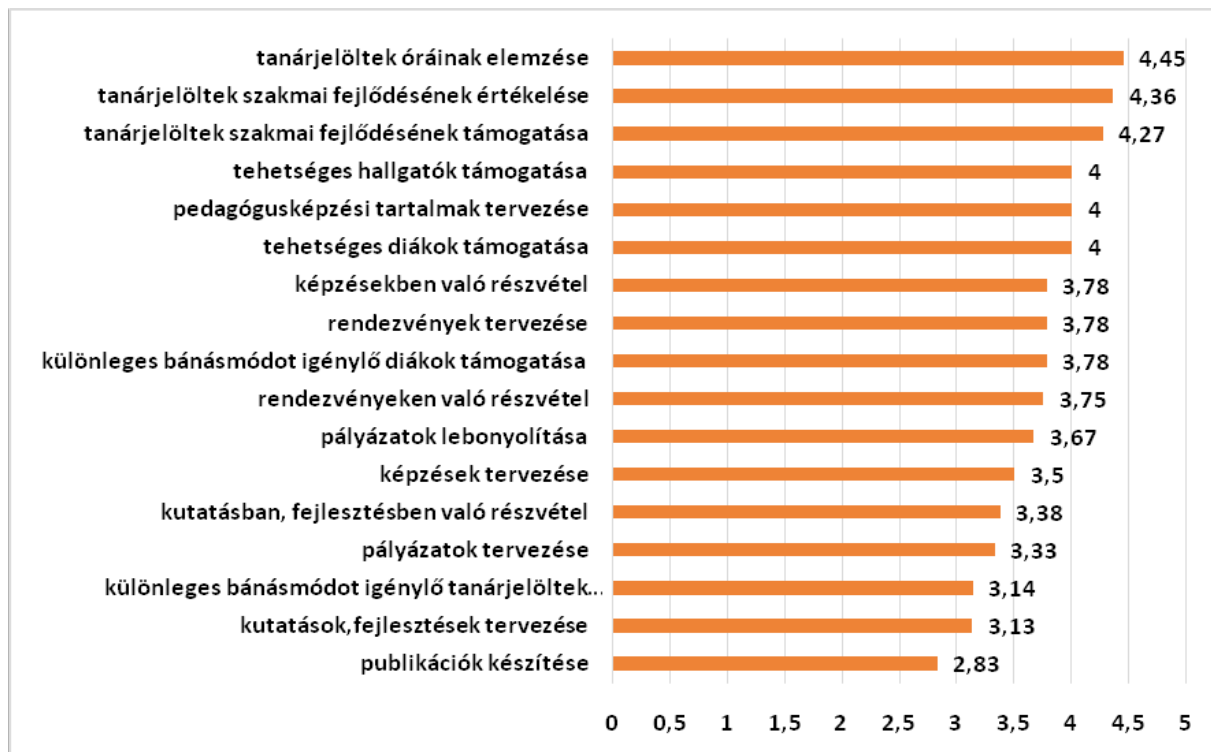

6. ábra: A gyakorlóiskolai tanárokkal való együttműködés elégedettsége (5-fokú Likertskála) (N=11) (készítette: Bencze Rita)

Ami pedig az oktatók elégedettségét illeti a gyakorlóiskola egyetemmel való együttműködésével a kutatásban, fejlesztésben való részvétel esetében a 3,38-as átlag közepes elégedettséget jelez (Mennyire ítéli eredményesnek az együttmúködést?, Oktatói kérdőív, 17.) még kisebb ez az érték a kutatások, fejlesztések tervezése $(3,13)$ és a publikációk készítése területén $(2,83)$ (6. ábra). Sorrendileg a három részterület a 17 kategóriából a 13., 16. és 17. helyet foglalja el. Ez azt mutatja, hogy az oktatók véleménye szerint a gyakorlóiskola pedagógusai nem lépnek fel aktív kezdeményezőként, a gyakorlati problémák megoldásához vezető magasabb szintű reflektivitás dimenziójának megvalósításához.

\section{A gyakorlóiskola és a hallgatók}

Az egyetem és a gyakorló iskola együttmüködését a szakmai fejlesztés vonatkozásában érdemes megvizsgálni a hallgatók szempontjából is (Hallgatói kérdoív 15.). A válaszadók egy 5 fokozatú skálán értékelték a lehetséges válaszokat: 
Pedagógusképzés • 18(46), 2019/1-2.

\begin{tabular}{|c|c|c|c|c|}
\hline \multicolumn{5}{|c|}{$\begin{array}{c}\text { Ön mennyire elégedett az alábbiakkal? } 1 \text { = egyáltalán nem vagyok elégedett, } 2 \text { = inkább } \\
\text { nem vagyok elégedett, } 3 \text { = elégedett vagyok meg nem is, } 4=\text { inkább elégedett vagyok, } 5 \\
\text { = teljes mértékben elégedett vagyok }\end{array}$} \\
\hline \multicolumn{5}{|c|}{$\begin{array}{c}\text { a hallgatók elé- } \\
\text { gedettsége az } \\
\text { egyetemi képzés } \\
\text { és az iskolai saját szaktárgyi } \\
\text { gyakorlatok tar- felkészültség }\end{array}$} \\
\hline átlag & 2,89 & 4,05 & 4,11 & 3,94 \\
\hline
\end{tabular}

A hallgatók bár kevesen töltötték ki a kérdőívet (22 fö), a mért adatok átlagai alapján nem igazán elégedettek az egyetemi képzés és az iskolai gyakorlatok közötti tartalmi összhanggal, ami felveti az egyetem és a gyakorlóiskola együttműködésének a hiányosságait (12. táblázat). Saját pedagógiai és pszichológiai és szaktárgyi felkészültségüket jó színvonalúnak ítélik meg. A módszertani felkészültségüket kissé alacsonyabbra értékelik. A válaszadók szerint az egyetemi kurzusok a szakmai tudáson belül a munkaformák (16 fö), a szaktárgyi tudás (12 fó), a pedagógiai tudás (11 fö), a tanári önreflexió (10 fő), a pszichológiai tudás (10fó) és a szakmódszertani tudás (10 fő) vonatkozásában adják a legtöbbet a tanári professzióra való felkészülésben. A kollégákkal való együttmüködés (0fó), a felzárkóztatás (1 fő), az osztályfőnöki feladatok (1 fő), a szülőkkel való együttműködés (1 fó), a fegyelmezés (1 fó) területein a válaszadók közül igen kevesen kapnak felkészítést (Mely területeken biztosították leginkább az egyetemi kurzusok a tanári professzióra való felkészítést?, Hallgatói kérdőív 17.).

A gyakorlóiskola az óravezetés (16 fó), a munkaformák (15fo), a szakmódszertani tudás (15 fó), a pedagógiai tervezés (13 fö) területén készíti leginkább fel a hallgatókat a pályára. Hiánynak érzik a szülőkkel való együttműködés (0 fö) és az osztályfőnöki feladatok (1 fö) területein való felkészítést (Mely területeken biztosították leginkább a gyakorlóiskolai feladatok a tanári professzióra való felkészülést?, Hallgatói kérdőív 18.). Azok a válaszadók, akik alacsonyra értékelik az egyetemi képzés és a gyakorlóiskola tartalmi összhangját a leggyakrabban az egyetemi képzés gyakorlatorientáltságát nevezik meg hiányként (8 fő), (Kérjük, jelölje meg, hogy mennyire elégedett az alábbiakkal!, Hallgatói kérdőív 15.). A hallgatók bizonyos szervezésből adódó ütközéseket is megemlítenek, például. a módszertani 
gyakorlat később van az egyetemen, mint a gyakorlóban, vagy ütköznek a hallgató órarendjében az egyetemi órák és a gyakorlóiskolai feladatok.

Szembetűnően alacsony a hallgatók együttműködése a gyakorlóiskola más szaktanáraival. A 22 válaszadóból 1 fő vett részt tantestületi, 1 fő munkaközösségi megbeszélésen (Részt vett Ön az iskolai gyakorlatai során nevelőtestületi értekezleten?, Hallgatói kérdőív, 21., és Részt vett Ön az iskolai gyakorlatai során munkaközösségi megbeszélésen?, Hallgatói kérdőív, 23.). Vagyis a gyakorlóval való kapcsolatot a pedagógusok vonatkozásában csakis a szakvezető jelenti a hallgatók számára.

A kérdőív nyílt kérdésére adott válaszai alapján összehasonlító a gyakorlóiskolai tevékenység és a féléves tanítási gyakorlat (Miben látja a leglényegesebb különbséget az egri tanítási gyakorlat és a féléves tanítási gyakorlat között?, Hallgatói kérdőív, 27. nyílt kérdés). A hallgatók a gyakorlóiskolai tevékenység mellett sorolnak fel olyan érveket, mint a részletes, dokumentált óratervezés, a diákok jó fegyelmi helyzete és motiváltsága, a szakvezető módszertani felkészültsége. Ugyanakkor igen sok pozitív elemet neveznek meg a féléves tanítási gyakorlatukra vonatkozóan is felismerve a két gyakorlat közötti funkcionális különbséget: nagyobb önállóság, több fejlődési lehetőség, több idő a diákokkal való kapcsolat alakítására, több lehetőség az iskola, mint intézmény megismerésére.

A hallgatók nézeteinek vizsgálata alapján megállapítható, hogy a gyakorlóiskola és benne a magas szakmai színvonalat képviselő szakvezető nagyon fontos szerepet játszik a tanári professzióra való felkészítésben. Alátámasztást nyert negyedik hipotézisünk (H4), amelyik szerint a gyakorlóiskolai pedagógusok magas szintű szakmai tudása és a pálya iránti elkötelezettsége hat a hallgatók nézeteire. A gyakorlóiskolai jelenlét elsősorban a tanóra keretein belüli gyakorlati tapasztalatok szerzését biztosítja a hallgatóknak. Hiányként jelenik meg a szélesebb szakmai kontextusba való bekapcsolódás biztosítása a hallgató számára a szakmai fejlesztés vonatkozásában. Ötödik hipotézisünk (H5), azaz a pedagógusok törekszenek a tanárjelöltek bevonására az iskola szakmai önfejlesztő tevékenységébe elhivatottságuk növelése érdekében, nem nyert alátámasztást.

Szintén hiányként nevezhető meg az egyetem és a gyakorlóiskola összehangoltabb együttmúködése mind tartalmi, mind szervezési oldalról. Korábban a pedagógusok nézeteit elemezve a 4. táblázat alapján azt a következtetést vontuk le, hogy a pedagógusok nem tulajdonítanak kiemelkedő szerepet az egyetem és a gyakorló együttműködésének, a hallgatók nagyobb támogatásának a Szakmai Fej- 
lesztő Iskolává váláshoz. Mindez tetten érhető a hallgatók nézeteiben, többet várnak a gyakorlóiskolától: a tanórákra korlátozott szakmai tudás megosztás tanórán kívüli tudásmegosztássá való szélesítését. Ezért jövőbeli feladatként fogalmazható meg a hallgatóknak a tanítás szélesebb kontextusába való bevezetése például pedagóguskollégákkal, szülőkkel való kapcsolattartás fejlesztése, fegyelmezési problémákra való felkészítés, valamint az egyetem és a gyakorlóiskola tartalmi és szervezési kérdésekben való nagyobb fokú kooperációja.

\section{A gyakorlóiskola önfejlesztö tevékenysége és a szülök}

Ennek a kérdéskörnek a központi eleme az, hogy a gyakorlóiskola önfejlesztő tevékenysége hogyan tükröződik a szülők nézeteiben. Egyáltalán tudatosul-e bennük, és ha igen, milyen mértékben? A szülők szerint van-e szerepe az önfejlesztésnek gyermekeik fejlődésében?

Először is azt szerettük volna megvizsgálni, hogy mennyire játszott szerepet a szülők iskolaválasztásában a szakmai színvonal, a pedagógusok magas szintű szakmai felkészültsége (Szülői kérdőív 7.). Az összes kategóriából itt azokra fókuszáltunk, amelyek a minőségi munka mutatói. Ezek után megnéztük, hogy elvárásaik mennyiben teljesültek, elégedettek-e az iskola és a pedagógusok munkájával (Szülői kérdőív 9.), valamint tulajdonítanak-e valamilyen szerepet gyermekük fejlődésében az iskola és a pedagógusok erőfeszítéseinek a szakmai színvonal emelésére. 


\begin{tabular}{|c|c|c|}
\hline $\begin{array}{l}\text { kategóriák } \\
\quad N=247\end{array}$ & $\begin{array}{l}\text { Kérjük, értékelje, hogy mennyire } \\
\text { tartotta fontosnak az alábbi } \\
\text { tényezőket, amikor a } \\
\text { gyakorlóiskolát választotta } \\
\text { gyermeke számára! Nagyon } \\
\text { fontos az iskolaválasztásnál/ } \\
\text { gyakoriság (fó, százalék) }\end{array}$ & $\begin{array}{l}\text { Kérjük, értékelje, hogy } \\
\text { mennyire elégedett } \\
\text { most ugyanezekkel a } \\
\text { tényezőkkel! (1-5 } \\
\text { elégedettségi skála) } \\
\text { elégedettség/átlag }\end{array}$ \\
\hline a pedagógusok jól tanítanak & $230(93,1)$ & 4,11 \\
\hline $\begin{array}{l}\text { a pedagógusok szaktárgyi } \\
\text { tudása kiemelten jó }\end{array}$ & $220(89,1)$ & 4,34 \\
\hline $\begin{array}{l}\text { színvonalas az idegen nyelvek } \\
\text { oktatása }\end{array}$ & $212(85,8)$ & 4,38 \\
\hline a pedagógusok kiváló nevelők & $205(83)$ & 4,03 \\
\hline elismerten jó iskola & $186(75,3)$ & 4,4 \\
\hline $\begin{array}{l}\text { sok gyerek tanul tovább jó } \\
\text { egyetemen }\end{array}$ & $168(68)$ & 4,55 \\
\hline színvonalas a tagozatos képzés & $148(59,9)$ & 4,38 \\
\hline $\begin{array}{l}\text { színvonalas az informatika } \\
\text { képzés }\end{array}$ & $120(48,6)$ & 3,94 \\
\hline $\begin{array}{l}\text { színvonalas a múvészeti } \\
\text { képzés }\end{array}$ & $87(35,2)$ & 4,34 \\
\hline
\end{tabular}

13. táblázat: Szülői elvárások és azok teljesülése

Az iskolaválasztásnál az összes kategória közül is a legfontosabb elvárás a szülők nézetei szerint, hogy a pedagógusok jól tanítsanak (13. táblázat). Még az első öt kategóriába tartozik a pedagógusok magas szintű szaktárgyi tudása. Az első tíz kategóriába bele tartozik a színvonalas idegen nyelvoktatás, a kiváló nevelés, a mindezek által biztosított jó hírnév és hogy sok diák tanul tovább jó főiskolákon és egyetemeken. Az iskolaválasztást és az elégedettséget meghatározó első tíz kategóriában a magas szakmaiság $60 \%$-os részesedéssel van jelen. A belső arányok azonban az elégedettségnél megváltoznak. Ott az első öt kategóriában csak egy jelenik meg, méghozzá a jó továbbtanulási arány. Az, hogy elismerten jó az iskola, színvonalas az idegen nyelvek tanítása, a tagozatos képzés, a művészeti képzés és a pedagógusok kiemelten jó szaktárgyi tudással rendelkeznek csak a második öt kategóriába került besorolásra. Az, hogy a pedagógusok jól tanítanak az elégedettség rangsorában csak a tizennegyedik helyet, illetve hogy kiváló nevelők a tizenötödik helyet kapta. 
Szerettük volna megtudni, hogy a szülők szerint milyen tényezők azok, amelyek elősegítik az iskola színvonalának növelését (Szülői kérdőív 23.).

\begin{tabular}{l|c}
\hline $\begin{array}{c}\text { Ön szerint milyen mértékben akadályozzák vagy segítik az alábbi tényezók } \\
\text { az iskola szakmai színvonalának emelkedését? nagymértékben } \\
\text { akadályozza, inkább akadályozza, részben akadályozza, részben segíti, } \\
\text { inkább segíti, nagymértékben segíti, nem befolyásolja, nem tudom } \\
\text { megítélni } \\
\text { kategóriák } \\
N=247\end{array}$ & átlag \\
\hline bontott csoportok & \\
tanórákhoz szükséges eszközök & 4,75 \\
az iskola infrastruktúrája & 4,65 \\
a pedagógus motiváltsága & 4,64 \\
tanulók motiváltsága & $\mathbf{4 , 5 3}$ \\
tantermek berendezése & 4,45 \\
tanulók tudásszintje iskolába lépéskor & 4,43 \\
órarend & 4,34 \\
a pedagógus munkaterhelése & 4,03 \\
$\quad$ 14. táblázat: A szülők értékelése az iskola színvonalát befolyásoló tényezőkről
\end{tabular}

Elsősorban az iskolai élet szervezésével, felszereltségével kapcsolatos tényezők azok, amelyek a szülők véleménye szerint meghatározó szerepet játszanak a színvonal emelésében (14. táblázat). Az emberi tényező és azon belül a pedagógus csak a negyedik helyen jelenik meg először a rangsorban.

Tovább elemezve az iskola fejlesztésére vonatkozó szülői javaslatokat mi elsősorban a szakmai munka színvonalára vonatkozókat vettük górcső alá. Külön nyílt kérdéssel is rákérdeztünk, hogy a szülők szerint melyik három területen kellene az iskolának leginkább javítania (Kérjük, sorolja fel azt a három területet, hiányosságot, amelyeken az Ön véleménye szerint a legfontosabb lenne, hogy a gyakorlóiskola változtasson! Szülői kérdőív, 29.).

A 232 válaszadóból 96 fó tett javaslatot a szakmai munkára vonatkozóan. A szülői válaszokat tartalomelemzéssel nagyobb csoportokba soroltuk és így született meg 19 fó kategória. A legtöbben a szak- és nevelésmódszertani felkészültség javítását említették (23 megnevezés). Nagyon fontosnak tartják a differenciálást és az egyéni bánásmód alkalmazását (22), az órarend zsúfoltságából és ésszerủtlenségéből adódó nehézségek leküzdését (15), valamint a pedagógusok empatikus készségeinek, gyermekközpontúságának erősítését (13). 
Az iskola pályázati tevékenységének értékelésére is kíváncsiak voltunk a szülők szemszögéből, ezért kérdeztük meg, hogy eredményesnek tartják-e azt (Véleménye szerint eredményes a gyakorlóiskola pályázati tevékenysége?, Szülői kérdőív 24. lásd 9.1. táblázat.). A válaszadók több, mint fele (65,7\%) eredményesnek itélte meg ezt a tevékenységet, de figyelemre méltó azoknak az aránya, akik úgy érzik, hogy nem tudják megítélni (42,7\%). Ez továbbgondolásra késztetett bennünket. Talán szükséges lenne valamilyen hatástanulmányt készíteni a pályázatok vonatkozásában, amellyel tisztázni lehetne az általuk biztosított hozzáadott értéket. A továbbiakban pedig az iskola vezetése ezt kommunikálni tudná mind a kollégák, a fenntartó és a szülők irányába.

Hatodik hipotézisünk (H6), amelyik szerint a szülők iskolával szemben megfogalmazott elvárásaiban fontos szerepet kap a pedagógusok folyamatos szakmai fejlődése, amely gyermekeik fejlődésének alapvető feltétele, ennek alapján értékelik az iskola eredményességét csak részben nyert alátámasztást. A megkérdezett szülők iskolaválasztását nagyon is befolyásolta a gyakorlóiskola szakmai színvonala, ugyanakkor jelen esetben kevésbé elégedettek azzal. Az iskola szakmai színvonalának további növeléshez nem elsősorban a pedagógusok szakmai fejlődését tarják fontosnak, hanem szerintük a szervezés és az infrastruktúra javítása viszi előre az iskolát. A pályázatok hatásának szülői megítélésére vonatkozóan azért nehéz következtetéseket megfogalmazni, mert nagyon sokan nem tudják azt megítélni, így az iskola vezetés számára további feladatokat jelent a hatások felmérése és kommunikálása a szülők felé.

\section{A gyakorlóiskola önfejlesztö tevékenysége és a diákok}

A tanulók nézeteit vizsgálva a gyakorlóiskola szakmai önfejlesztésére vonatkozóan az volt számunkra a kiinduló kérdés, hogy tudatában vannak-e a diákok, hogy ez az intézmény magasabb elvárásokat fogalmaz meg az őket tanító pedagógusokkal szemben, mint egy másik iskola. Ennek kiderítésére először is arra kérdeztünk rá, hogy tisztában vannak-e azzal, hogy a pedagógusaik a legmodernebb módszerekkel tanítják őket (Felsős tanulói kérdőív, 9.). 
Pedagógusképzés • 18(46), 2019/1-2.

\begin{tabular}{l|cc}
\hline $\begin{array}{c}\text { Szerinted a tanáraid a legmodernebb } \\
\text { módszerekkel tanítanak Titeket? igen, nem, } \\
\text { nem tudom } \\
\text { kategóriák } \\
N=255\end{array}$ & gyakoriság (fó) & \\
relatív gyakoriság/\% \\
\hline igen & 115 & \\
nem & 55 & 45,1 \\
nem tudom & 85 & 21,6 \\
összes & 255 & 33,3 \\
\hline
\end{tabular}

15. táblázat: A pedagógusok által alkalmazott új módszerek megítélése a tanulók szerint

A válaszadó tanulók, mintegy 67\%-a nyilatkozott úgy hogy igenis tisztában vannak tanáraik módszertani felkészültségével, és a 67\%-nak kétharmada gondolja úgy, hogy modern módszerekkel tanítanak, egyharmaduk pedig, hogy nem. Nem hanyagolható azonban el, hogy körülbelül egyharmada a teljes mintának nincs tisztában azzal, hogy milyen módszerekkel tanítják őket tanáraik (15. táblá$z a t)$.

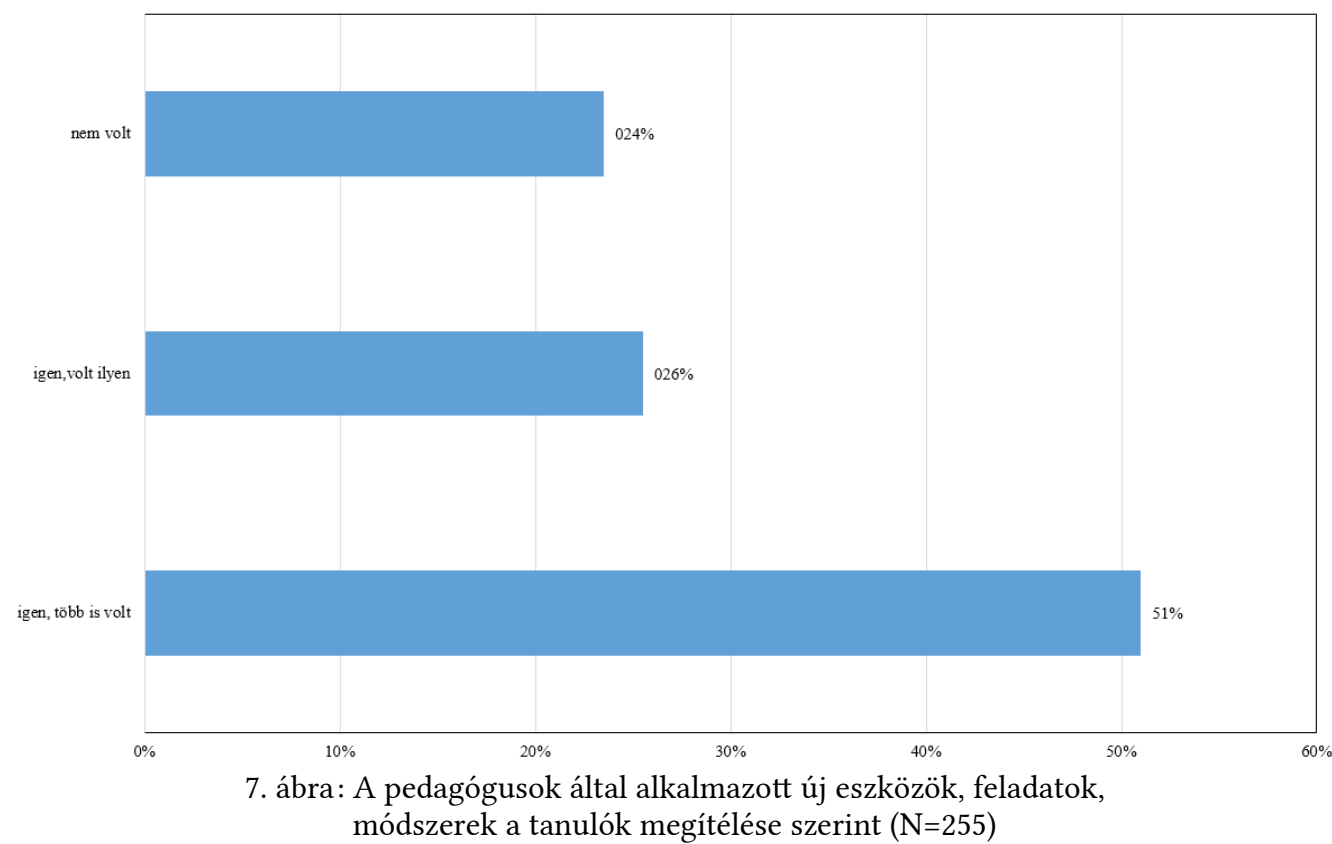

Ezt a kérdést kicsit mélyebben kibontva (Az elmúlt tanév során volt-e olyan, számodra új eszköz, feladat, vagy módszer, amelyet a tanáraitok kipróbáltak veletek az órán, és tetszett neked?, Felsős tanulói kérdőív 10.) az is kiderült, hogy a 
válaszadók nagy többsége (76,50\%) érzékelte, hogy az elmúlt tanévben a pedagógusok egy vagy több alkalommal is valamilyen új eszközt, módszert, vagy feladatot használtak fel a tanítás során (7. ábra). A válaszadók fele úgy nyilatkozott, hogy több alkalommal is sor került erre.

Fontos volt kideríteni, hogy a diákok saját fejlödésüket az elmúlt tanévben minek tulajdonították, és hogy tetten érhető-e az okok között a pedagógusok szakmai fejlődése (Szerinted miért fejlődtél?, Felsős tanulói kérdőív 25.) A fejlődésük legfőbb okának saját motivációjukat jelölték meg (56\%). A rangsorban harmadikként jelennek meg a pedagógusok által alkalmazott új módszerek (13,9\%=69fó), majd ötödikként az új eszközök használata a tanulás során (9,8\%=49 fö). Igen kevesen jelölték meg a külön felzárkóztatást, a korrepetálást és a tehetséggondozást. A diákok első okként megjelenő nagyobb motivációja a pedagógusok szakmai fejlődésének indirekt mutatója, az új szakmai ismeretek, készségek elsajátítása motiválja a pedagógust a gyakorlatban történő alkalmazásra. A 498 válaszból 162 válasz $(32,5 \%)$ direkt módon utal a pedagógusok szakmai fejlődésére. Ezen belül az új módszerek, eszközök egyharmada bizonyul tehát eredményesnek diákok szerint. A hetedik hipotézisünk (H7) is alátámasztásra került, vagyis a pedagógusok szakmai fejlődése tetten érhető a diákok nézeteiben, mindez erősíti a tanulás hatékonyságát.

Összehasonlítottuk a szülők és a diákok nézeteit ebben a kérdésben (Ön szerint mi az oka gyermek fejlődésének?, Szülői kérdőív, 20., és Szerinted miért fejlődtél?, Felsős tanulói kérdőív, 25.).

\begin{tabular}{|c|c|c|}
\hline rangsor & $\begin{array}{c}\text { A szülők megítélése szerint a } \\
\text { gyermekek fejlődésének oka } \\
(N=247)\end{array}$ & $\begin{array}{l}\text { A diákok megítélése szerint saját } \\
\text { fejlödésük oka }(N=255)\end{array}$ \\
\hline 1. & $\begin{array}{l}\text { nagyon jó személyes kapcsolat a } \\
\text { tantárgyat tanító pedagógussal }\end{array}$ & jobban érdekelte a téma \\
\hline 2. & $\begin{array}{l}\text { jobban érdekelte gyermekét a } \\
\text { téma }\end{array}$ & szorgalmasabb volt \\
\hline 3. & gyermeke szorgalmasabb volt & új módszerekkel tanított a tanár \\
\hline 4. & jobb módszerek alkalmazása & $\begin{array}{l}\text { nagyon jó személyes kapcsolat a } \\
\text { tantárgyat tanító tanárral }\end{array}$ \\
\hline 5. & $\begin{array}{l}\text { új és többféle eszköz használata a } \\
\text { tanulásban }\end{array}$ & $\begin{array}{l}\text { új eszközök használata a tanulás } \\
\text { során }\end{array}$ \\
\hline 6. & különórák & felzárkóztatás, korrepetálás \\
\hline 7. & tehetséggondozás & tehetséggondozás \\
\hline 8. & korrepetálás & - \\
\hline
\end{tabular}


Mindkét csoportnál egyaránt a motiváció növekedése a jobb tanulmányi eredmény oka (16. táblázat). A szülőknél azonban kiemelkedően fontos a tantárgyat tanító pedagógussal való jobb kapcsolat. Ugyanez a tényező a diákoknál csak negyedik a rangsorban. A diákoknál inkább a téma iránti érdeklődés és a szorgalom a motiváció fő oka. A pedagógusok szakmai fejlődése, ami elsősorban az új módszereket jelenti a szülőknél a negyedik, a diákoknál a harmadik a rangsorban. Megállapítható, hogy a szülők és a diákok nézetei sok tekintetben lefedik egymást. A szülők épp úgy, mint az iskolaválasztásnál fontos szerepet tulajdonítanak a pedagógus személyének. A rangsor vége felé jelenik meg a tehetséggondozás, a korrepetálás és a felzárkóztatás mindkét csoportnál. Ez megfontolásra érdemes mind az iskolavezetés, mind pedig a pedagógusok számára.

\section{Összegzés}

Tanulmányunkban a pedagógusok, oktatók, hallgatók, diákok és szülők nézeteit vizsgáltuk meg a szakmai fejlesztés szempontjából. Célunk az volt, hogy feltérképezzük, az Eszterházy Károly Gyakorlóiskola példáján keresztül, hogy a Szakmai Fejlesztő Iskolává váláshoz milyen lépéseket szükséges megtenni a jövőben.

A rendelkezésre álló adatok alapján egyértelműen kijelenthető az adott intézmény vonatkozásában, hogy:

- az iskolavezetés és a pedagógusok is a szakmai fejlesztés és fejlődés elsődlegességét vallják, a magas szintủ szakmai tudást elsősorban az iskolában tanuló gyermekek fejlesztése érdekében kívánják felhasználni;

- a pedagógusok magasra értékelik szakmai tudásukat, és intenzíven tesznek is e tudás fejlesztéséért;

- a pedagógusok a gyakorlóiskola tudásmegosztó szerepének nem tulajdonítanak nagy jelentőséget, és ez tükröződik a tudásmegosztásban résztvevők számában;

- az egyetemmel való együttmúködést és a hallgatók támogatását kevésbé tartják fontosnak a pedagógusok, az egyetemmel való közös kutatások eredményeinek a megítélése nem egyértelmủen pozitív, viszonylag kevesen vesznek részt ilyen kutatásokban, inkább saját szakmai tudásuk fejlesztésében kamatoztatják az egyetemmel való kooperációt;

- a gyakorlóiskolai pedagógusok magas szintű szakmai tudása és a pálya iránti elkötelezettsége nagymértékben hatással van a hallgatók nézeteire, ugyanakkor a hallgatók többet várnak az egyetemtől és a gyakorlóiskolá- 
tól: kedvezőbb lenne számukra, ha a képzés tartalmi és szervezési vonatkozásában hatékonyabb egyeztetés valósulna meg a két intézmény között, másrészt a gyakorlóiskolai, a tanórára fókuszáló képzést szeretnék kitágítani az egész iskolára és az iskolai környezetre is;

- a szülők számára az iskolaválasztásban nagyon fontos a pedagógusok szakmai tudása, ugyanakkor gyermekük bekerülése után kevésbé elégedettek azzal;

- az iskola szakmai színvonalának további növeléshez nem a pedagógusok szakmai fejlődését tarják fontosnak, hanem a szervezés és az infrastruktúra javítását;

- a pályázatok hatását a szakmai színvonal emelésére nem sokan tudják érdemben megítélni, ami az iskola vezetése számára további feladatokat jelent;

- a diákok nézeteiben direkt és indirekt módon is tükröződik a pedagógusok szakmai fejlődésre vonatkozó igénye, ez pedig erősíti a tanulásuk hatékonyságát.

Mindezen eredmények ismeretében következtetésként fogalmazhatjuk meg a gyakorlóiskolák Szakmai Fejlesztő Iskolákká történő átalakuláshoz, hogy az aláfölérendeltségi viszonyt alapvetően szükséges átalakítani egyenrangú partneri viszonnyá. A jelenlegi viszony hozadéka a jövőre nézve, hogy a partnerintézmények munkatársai (vezetők, pedagógusok, oktatók) személyesen is ismerik egymást. E személyes kapcsolatok az egységes szemlélet és fejlesztési koncepció kialakításának kiindulópontját jelenthetik. A kölcsönösségen alapuló kommunikáció egy olyan párbeszéd megindítását eredményezheti, amelyben a partnerek a Szakmai Fejlesztő Iskolává történő átalakulásra vonatkozó elképzeléseiket ütköztethetik, egyeztethetik. Természetesen ehhez szükséges a képzőhely és a gyakorlóhely vezetésének szemléletbeli változása. Felvetődik a kérdés, hogy melyek azok az alapvetések, amelyekről szükséges a párbeszéd megindítása. Kutatási eredményeink alapján kétségkívül elmondható, hogy a kutatásalapú pedagógusképzés jelenti az egyik alapvetést. Hogy mit kellene kutatni? Itt utalnánk a méltányosság fogalmára. Azt kellene ismerni, hogy az iskolában tanuló diákok milyen egyéni tanulási igényekkel rendelkeznek és ezeknek az igényeknek a kielégítéséhez milyen módszereket, eszközöket, tanulási környezetet szükséges biztosítani. Ezekhez szükséges igazítani a pedagógusok és az oktatók szakmai fejlődését és a tanárjelöltek képzését. Lehetséges-e olyan feltételeket (pénzügyi, szervezeti, inf- 
rastrukturális) megteremteni, amelyek biztosítják, hogy a gyakorlóhely pedagógusai és az ott gyakorló tanárjelöltek szélesebb körben kapcsolódjanak be kutatásokba, kezdeményezőivé váljanak ezeknek a kutatásoknak, és ne csak végrehajtói legyenek? A másik alapvetés, ami a kutatásalapú pedagógusképzés megvalósításához szükséges a tanárjelöltek számára a szélesebb szakmai kontextus megtapasztalása (tantestületi szintű vagy, kiscsoportos megbeszélések, kutatóműhelyekben való részvétel, szakmai továbbképzésekbe való bekapcsolódás, a szülőkkel való kapcsolattartás és kommunikáció, az osztályfőnöki munka szélesebb körébe való bevezetés). Érdemes lenne a hallgatók véleményét többször is kikérni, hiszen a Szakmai Fejlesztő Iskola, nem csak a diákokról, hanem a leendő pedagógusokról is szól. Természetesen ez számos tartalmi és szerkezeti változtatást is igényel a képzőhely (kutatások tervezése, tantervek, tanítási módszerek, szervezési módok, tanítási eszközök) és a gyakorlóhely tekintetében (kutatások tervezése, továbbképzések tervezése, humánerőforrás-gazdálkodás, órarendek tervezése, infrastruktúra fejlesztése). A harmadik alapvetés, hogy a szülőket hogyan lehet bevonni a Szakmai Fejlesztő Iskolává váláshoz szükséges diskurzusokba, melyek azok a pontok, ahol igenis szüksége van az iskolának a szülők visszajelzéseire, vagy akár személyes segítségére (itt most nem csak a tanórán kívüli iskolai rendezvényekre gondolunk). A kétirányú kommunikáció (szülők-intézmény) a felek számára erősebb kötődést jelentene. Végül pedig negyedik alapvetésként fontos a minőségbiztositás. Ennek eszközeként a szakmai önértékelést javasoljuk éves és ötéves periódusonként. Mindezen alapvetések megvitatásához azonban elengedhetetlen feltétel, hogy ne csak egyetlen kutatás alapján terjesszünk elő javaslatokat. Magyarországon minden pedagógusképzéssel foglalkozó egyetem egyedi profillal rendelkezik, szükséges lenne tehát a kutatói párbeszéd. 


\section{Irodalom}

Abdal-Haqq, I. (1998): Professional Development Schools: weighing the evidence. Corwin Press, Thousand Oaks.

Clark, R. W. (1999): Effective Professional Develpoment Schools. Agenda for Education in a Democracy V.3, Jossey-Bass, San Francisco. 28-65.

Darling-Hammond, L. (1994): Professional Development Schools: Schools to develop profession. Teacher College Press, New York.

Falus Iván (2002): A tanuló tanár, Iskolakultúra, 6. évf., 7. sz. 76-80.

Fountain, C. A. (1997): Collaborative agenda for change: Examining the impact of urban professional development schools. Paper presented at the Annual Meeting of the American Association of Colleges for Teacher Education, Phoenix, AZ. (ED 415 233)

Furlong, J. - Campbell, A. - Howson, J. - Lewis, S. - McNamara, O. (2006): Partnership in English initial teacher education: changing times, changing defi nitions. Evidence from the Teacher Training Agency's National Partnership Project. Scottish Educational Review, 37(1), 32-45.

Kopp Erika - Kálmán Orsolya (2015): Nemzetközi tapasztalatok elemzése a tanítási és az összefüggő egyéni tanítási gyakorlat terén, In: Rapos Nóra - Kopp Erika (szerk.): A tanárképzés megújitása- 2015. ELTE Eötvös Kiadó, Budapest.

Kotschy Beáta (2003): Szakmai fejlesztő/fejlődő iskolák - a pedagógusképzés megújításának egy lehetősége. Pedagógusképzés, 1. évf. 1-2. sz. 109-117.

Krist, D. - White, J. - Whitelaw, L. (2016): PDS Partnership Ideas to Promote College and Career Readiness, NAPDS Conference, 2016 March 3-6., PDS Partners, 11/3. p. 11., Washington D.C

National Council for the Accreditation of Teacher Education (2016): Professional Development Schools

http://www.ncate.org/ProfessionalDevelopmentSchools/tabid/497/Default.aspx Letöltés ideje: 2018. 02. 10.

Pennsylvania State University: What is a Professional Development School?, http://ed.psu.edu/pds/elementary/general-information/what-is-a-professionaldevelopment-school Letöltés ideje: 2018.03.02.

Pritchard, F. - Ancess, J. (1999): The effects of professional development schools: A literature review. Teachers College, National Center for Restructuring Education, Schools and Teaching, New York.

Professional Development Schools, NCATE Standars, http://www.ncate.org/ProfessionalDevelopmentSchools/tabid/497/Default.aspx Letöltés ideje: 2018. 07. 10. 
Romerdahl, N. - Gehrke, N. (1993): The shared leadership in teacher leaders and principals in professional development schools, Paper presented at the annual meeting of the AERA, Atlanta.

Schwartz, W. (2000):The Impact of Professional Development Schools on the Education of Urban Students. ERIC Digest, https://www.ericdigests.org/2001-2/urban.html Letöltés ideje: 2018.03.10.

Shen. J. (1993): Voices from the field: School-based faculty members vision of preservice teacher education in the context of a professional development school. (Occasional paper No.16.) University of Washington, Seattle.

Teitel, L. (2004): Two Decades of Professional Development School Development in the United States. What Have We Learned? Where Do We Go from Here?, Journal of In-service Education 30(3), 401-416.

The Holmes Group (1986): Tomorrow's teachers. East Lansing, http://files.eric.ed.gov/fulltext/ED399 220.pdf Letöltés ideje: 2018. 07. 10.

The Holmes Group (1990): Tomorrow's schools. East Lansing, http://files.eric.ed.gov/fulltext/ED399 220.pdf Letöltés ideje: 2018. 07. 10.

\section{Professional Development Schools as One of the Potential Models for Renewing Teacher Education}

There are several approaches to renewing the current system of Hungarian teacher education. One of them focuses on Teachers' Professional Development. The purpose of this study, conducted within the framework of a wide-scale empirical research project, is to explore the professional development opportunities provided by the faculty of the Educational Sciences of Eszterházy Károly University and its practice school. It also makes recommendations for the introduction of a new model of Professional Development Schools in Hungary based on the evaluation of the current system.

Keywords: teacher training, professional development, professional development school, practice school 